\title{
A Prospective Observational Study of Temporalis Fascia with Tragal Perichondrium as Graft Material in Type I Tympanoplasty
}

\author{
Dr Sai Kiran Gova ${ }^{1}$, Dr. V. Krishna Chaitanya ${ }^{2}$ \\ ${ }^{1}$ M.B.B.S, Reg. No: M175413021, Department of ENT Narayana Medical College \& Hospital Chintha Reddy Palem, Nellore - 524002 , \\ Andhra Pradesh, India \\ ${ }^{2}$ M. S., E.N.T., Professor, Department of ENT Narayana Medical College \& Hospital Chintha Reddy Palem, Nellore - 524 002, Andhra \\ Pradesh, India \\ Dr N.T.R. University of Health Sciences, Vijayawada, A.P., India
}

\begin{abstract}
A prospective observational study is performed on patients undergoing Type 1 Tympanoplasty after proper evaluation and obtaining a written informed consent for comparison of Temporalis fascia with Tragal Perichondrium as graft material in Type 1 Tympanoplasty and improvement is assessed with hearing improvement, time taken for graft uptake. A sample size of 100 patients in age group of 18 to 60 years in CSOM cases were selected for the study. Duration of study 2 years i.e. from October 2017 to September 2019.
\end{abstract}

Keywords: Temporalis fascia, Tragal perichondrium, Tympanoplasty, Chronic suppurative otitis media

\section{Introduction}

Tympanoplasty is a surgical procedure to eradicate the disease in the middle ear and to reconstruct the hearing mechanism with or without tympanic membrane grafting, whereas Myringoplasty is a surgery in which the reconstructive procedure is limited to repair of tympanic membrane perforation assuming that middle ear ossicles are functioning normally, eustachian tube is patent, and the patient has a good cochlear reserve $[1,2]$.

Type-1 tympanoplasty is surgical reconstruction limited to repair of tympanic membrane alone. The implicit definition is that the ossicular chain is intact and mobile and that there is no middle ear disease. In early centuries, an ear infection with complication was a life threatening condition. The introduction of antibiotics and the use of the operative microscope in the surgical field were revolutionary advances in the control of the disease. Chronic suppurative otitis media (CSOM) is a long standing infection of a part or whole of middle ear cleft. CSOM is characterized by ear discharge, a permanent perforation, and impairment of hearing. Tympanic membrane (TM) perforations lead to recurrent ear infections and hearing loss [1].

If the perforations are bilateral, hearing handicap becomes more evident. Persistent perforations occur either due to improper treatment of recurrent middle ear infections or infected traumatic perforation. Repair of TM perforation was attempted for many years. Different techniques and different graft materials like temporalis fascia, tragal perichondrium and tragal perichondrium with cartilage were used [3].

It is the work of two Germans, Wullstein and Zollner, which started in 1949, lead to a new concept of the treatment of deafness secondary to chronic infection in the middle ear and mastoid and the new method was called "tympanoplasty" [4].
Chronic suppurative otitis media is highly prevalent middle ear disease, particularly in the developing countries like India [5, 6]. It is defined as a persistent, disease affecting the mucoperiosteal lining of the middle ear cleft more than month which is insidious in onset, and capable of causing the destruction and some irreversible sequela, and also it clinically manifests with ear discharge and hard of hearing [7]. It causes numerous pathological changes in tympanic membrane, and middle ear such as perforation, ossicular destruction, myringosclerosis, tymapanosclerosis, granulation tissue polyp, cholesteatoma, etc. it causes significant conductive hearing loss. The surgical treatment of chronic suppurative otitis media primarily aims at eradication of disease process, and reconstruction of conductive hearing mechanism Tympanoplasty is surgical procedure to reconstruct sound conducting apparatus, tympanic membrane, ossicular system with or without grafting.

The primary goals of tympanoplasty are:

\section{Eradication of the disease}

2. To improve or maintain hearing mechanism

3. Establish middle ear cleft ventilation

For reconstruction of tympanic membrane, different types of materials are used. The most commonly used are temporalis fascia, cartilage, fascia lata etc. Temporalis fascia the most frequently used graft material, with closure of the tympanic membrane perforation. Cartilage has shown to be better graft material, to close perforations in the tympanic membrane. It gains popularity due to its resistance to retraction, resorption and reperforation, even with Eustachian tube dysfunction. The stiffness of cartilage that prevents reperforations, but it interfere with the sound conduction properties of the tympanic membrane, than temporalis fascia [1]. 


\section{International Journal of Science and Research (IJSR) \\ ISSN: 2319-7064}

ResearchGate Impact Factor (2018): 0.28 | SJIF (2018): 7.426

The present study is a prospective study which describes the influence of various parameters like type of graft used, surgical approach, the time taken for graft uptake,

\section{Objectives}

To observe and assess the difference between temporalis fascia, tragal perichondrium as graft material in Type 1 Tympanoplasty.

\section{Objectives}

To evaluate the Improvement in hearing by audiology with Pure Tone Audiometry

$>$ To study the effect of time taken for graft uptake on the audiological outcome.

\section{Review of Literature}

\section{Development of the ear}

The human ear development begins at the fourth week of embryonic life.

\section{External ear}

The auricle develops from auricular hillocks, derived from first and second branchial arches. The six hillocks develop in the 6-week of embryonic life. The external auditory meatus formed by deepening of the groove between the two arches. At the dorsal end of the first branchial groove, the ectodermal cells thicken and form the external meatus. These ectodermal cells proliferation forms a meatal "plug" that progress medially. Resorption of cells in the center of this meatal plug forms a tube-like structure which becomes ear canal. When complete canalization fails to occur that leads to External canal atresia [8].

\section{Middle ear}

The middle ear cavity forms as a lateral extension of the first pharyngeal pouch. The proximal end of this extension becomes the eustachian tube. The lateral extension joins with the ectoderm of the meatal plug and forms the tympanic membrane. From Mesoderm of the first branchial arch, the malleus, incus, anterior malleolar ligaments and tensor tympani muscle are derived. From the mesoderm of second arch, Stapes, stapedius muscle derived [9].

\section{Inner ear}

It has two components,

1.Membranous labyrinth. -derived from the ectoderm

2.Bony labyrinth- derived from the mesoderm and neural crest.
Valsalva maneuver in postoperative period on audiological outcome after surgery.
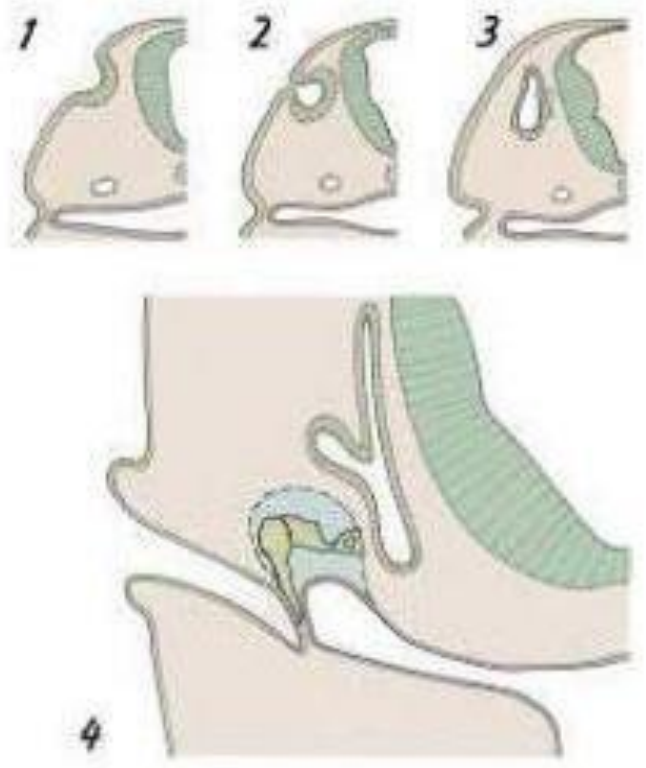

Figure 1: 1. Oticplacode, 2. Otic cup, 3. Otic cyst, 4. Inner ear

The membranous labyrinth develops from the otic placode which is a thickening of the ectoderm adjacent to the hindbrain. This otic placode invaginates and forms an otic cup. By the end of the fourth week, the edges of the otic cup fuse together form the otic vesicle/otocyst. A few of otic epithelial cells in the otic cup and otocyst separates from the epithelium and joins to form neurons of the eighth cranial nerve. These neurons innervate sensory organs within the inner ear.

A diverticulum develops in the otocyst elongates to form the endolymphatic duct and sac. The remaining portion of the otocyst enlarges and forms a ventral saccular and cochlear region, and the dorsal region develops into the utricle and three semicircular ducts.

The superior and posterior semicircular canals develop from a vertical outgrowth in the dorsal region of the otocyst. The lateral duct develops from a horizontal outgrowth in the lateral portion of the otocyst [8].

\section{The external auditory canal: Normal anatomy:}

The external auditory canal is approximately $2.5 \mathrm{~cm}$ in length and serves as a channel for sound transmission to the middle ear. Its lateral onethird is bolstered by elastic cartilage oriented in an upward and backward fashion; its anterior aspect is pierced by vertical fissures known as the fissure of Santorini. These fissures are a potential route for spread of infections or neoplasms between the external auditory canal and the parotid gland.

The medial two-thirds of the external auditory canal is osseous and is oriented in a downward and forward direction. Hence the auricle must be pulled upward and posteriorly to achieve lignment during otoscopic examination. The narrowest portion of the external 


\section{International Journal of Science and Research (IJSR) \\ ISSN: 2319-7064}

ResearchGate Impact Factor (2018): 0.28 | SJIF (2018): 7.426

auditory canal or isthmus is located just medial to the junction of the bony and fibrocartilagenous canal [10].

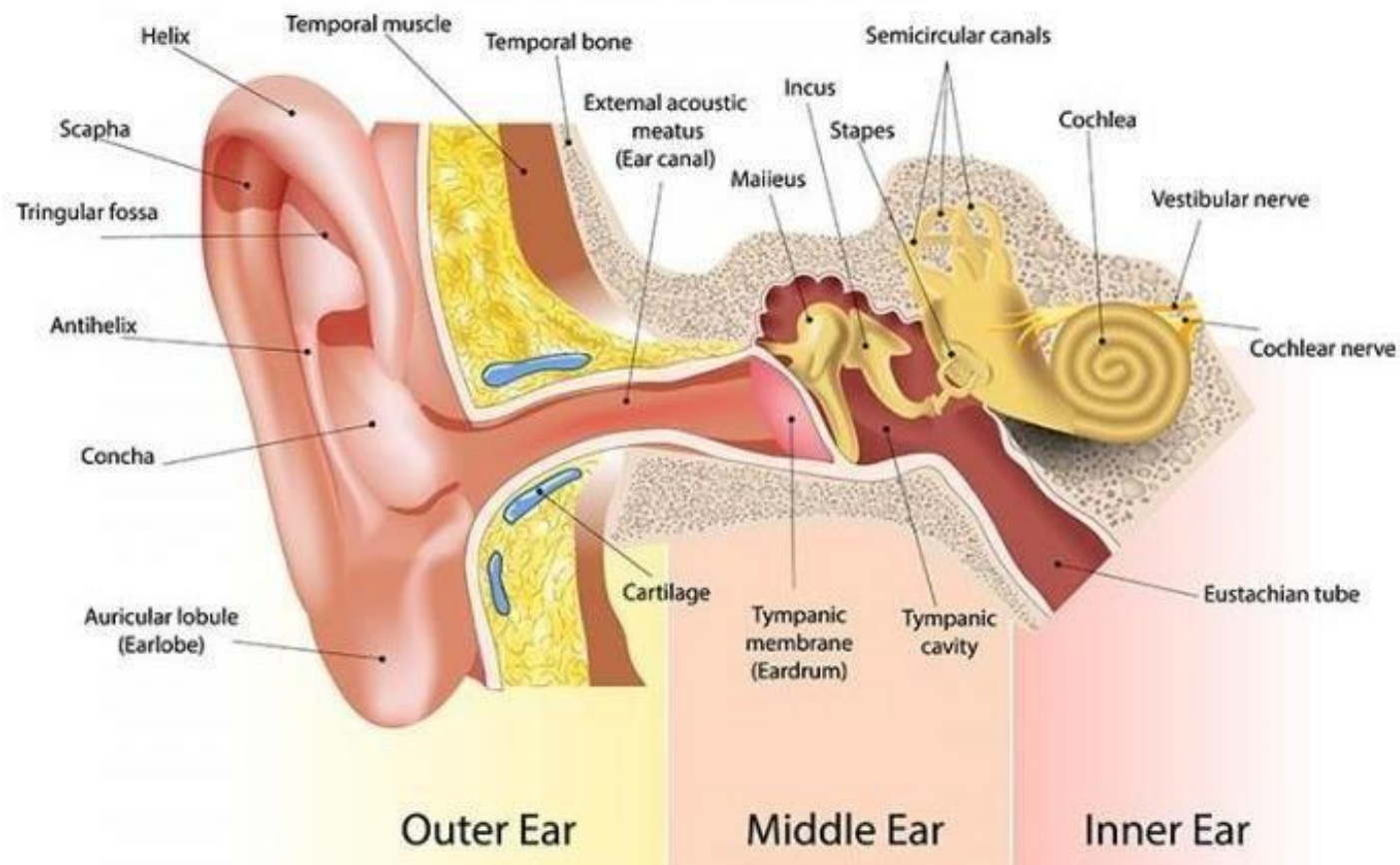

Figure 2: Anatomy of ear [11]

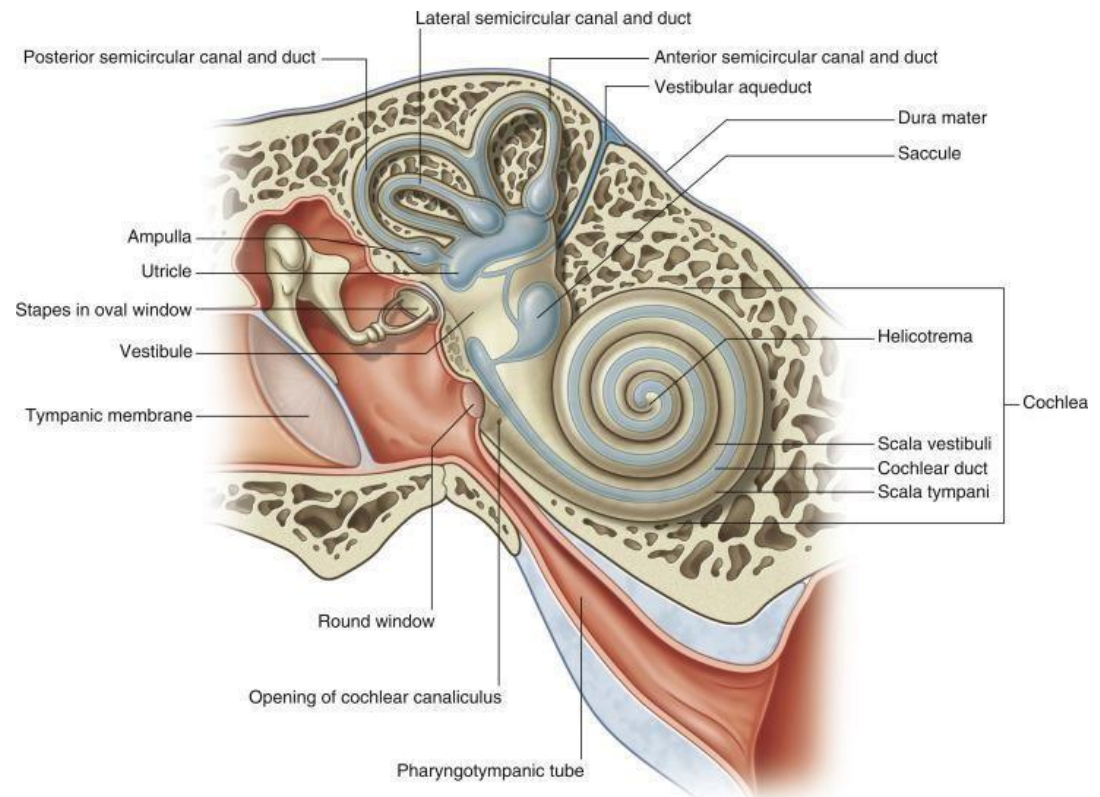

Figure 3: Middle ear [12]

Volume 8 Issue 12, December 2019

www.ijsr.net

Licensed Under Creative Commons Attribution CC BY 
The Tympanic membrane

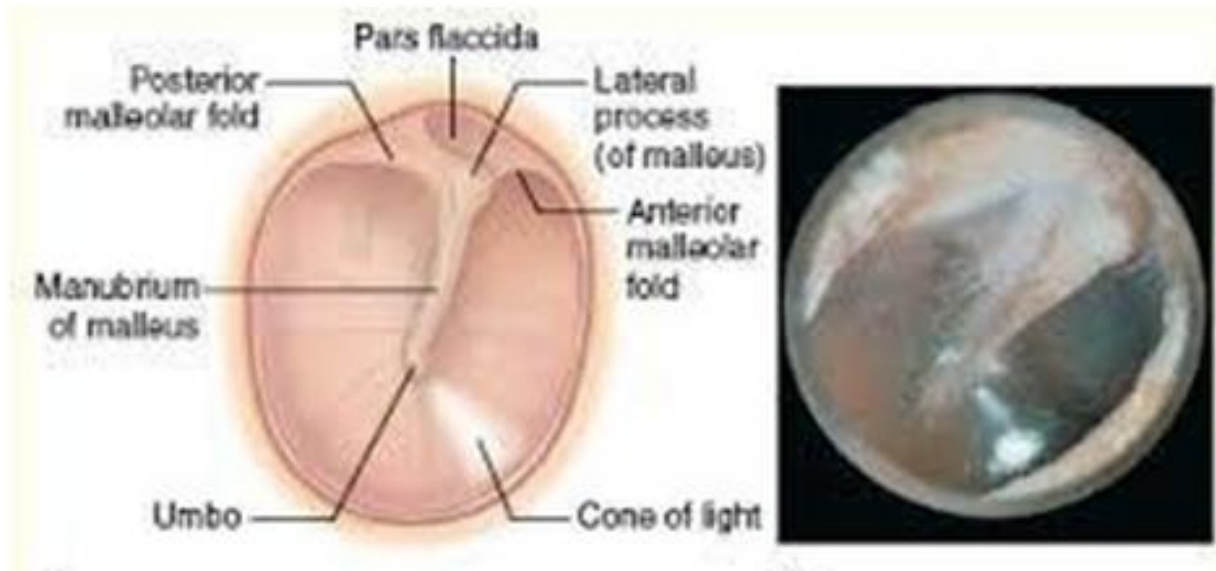

A

B

Figure 4: Tympanic membrane [13]

The tympanic membrane is irregularly round and slightly conical in shape. The apex of the cone is located at the umbo, which marks the tip of the manubrium. In the adult, it is angulated approximately $140^{\circ}$ with respect to the superior wall of the external auditory canal. The vertical diameter of the tympanic membrane as determined along the axis of the manubrium ranges from 8.5 to $10 \mathrm{~mm}$, while the horizontal diameter varies from 8 to $9 \mathrm{~mm}$.

The anterior and posterior tympanic striae extend from the lateral process of the malleus to the anterior and posterior tympanic spines, respectively. These striae divide the tympanic membrane into larger pars tensa below, and smaller triangular pars flaccida (or Shrapnell's membrane) above.

The thickened periphery of the pars tensa, the tympanic annulus anchors the tympanic membrane in a groove known as the tympanic sulcus. The tympanic annulus and sulcus are absent superiorly in the area of the notch of Rivinus.

The pars tensa, as its name suggests, is taut and consists of three layers:

- A lateral epidermal layer

- A medial mucosal layer

- An intermediate fibrous layer.

The pars flaccida, first described by Shrapnell, also consists of epidermal, fibrous, and mucosal layers. Here, the fibrous layer is scanty and consists of irregularly arranged collagen and elastic fibers [13].

\section{The ossicles:}

The three ossicles (malleus, incus, stapes) serve to transmit sound energy from the tympanic membrane to the inner ear [14].

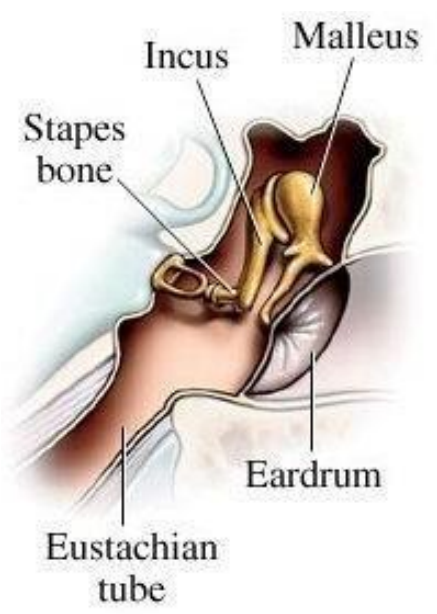

Figure 5: Ossicles [14]

\section{The malleus:}

It has a head, neck, lateral process, anterior process, and manubrium. It is held to the walls of the petrotympanic fissure by the anterior malleal ligament which, with the posterior incudal ligament, serves to establish the axis of rotation of the ossicles. On its thinner, medial aspect runs the chorda tympani nerve as it passes anteriorly to enter the iter chordae anterius at the Glaserian fissure.

The lateral process of the malleus contains a cartilaginous cap attached to the pars tensa of the tympanic membrane. The inferior end of the manubrium is firmly attached to the tympanic membrane as the pars propria splits to envelop it (the umbo).

The malleus is held in place by five ligaments, one articulation, the tensor tympani tendon, and the tympanic membrane.

Three of the five ligaments have a suspensory function. They are:

- The anterior suspensory ligament

- The lateral suspensory ligament 


\section{International Journal of Science and Research (IJSR) \\ ISSN: 2319-7064}

ResearchGate Impact Factor (2018): 0.28 | SJIF (2018): 7.426

- The superior suspensory ligament [14].

\section{The incus:}

The incus, the largest of the auditory ossicles, consists of a body, short process, long process, and lenticular process. The body of the incus rests in the epitympanum in association with the head of the malleus. The short process of the incus extends posteriorly, occupying the posterior incudal recess (fossa incudis).The long process reaches inferiorly, to end in the lenticular process; the convex surface of this process articulates with the concave surface of the head of the stapes. The long process of the incus is highly susceptible to osteitic resorption caused by chronic otitis media.

\section{The stapes:}

The stapes is the smallest ossicle. It consists of a head, footplate (the basis stapedis), and two crura or legs. The stapedius tendon attached to the superior aspect of the posterior crus. The footplate, in association with the annular ligament, seals the oval Window. The head articulates with the lenticular process of the incus at its fovea.

\section{The muscles}

\section{The Stapedius muscle:}

The stapedius muscle, the smallest of the skeletal muscles, emerges from the pyramidal eminence and attaches to the head and/or posterior crus of the stapes. It is supplied by facial nerve.

\section{The tensor tympani muscle:}

The tensor tympani muscle, arises from the cartilage of the eustachian tube, attach to the concave surface of the cochleariform (spoon-shaped) process, at which point the main body of the tendon turns laterally to attach to the medial and anterior surfaces of the neck and the manubrium of the malleus. Its innervation is from the trigeminal nerve. The action of the tensor tympani muscle is to draw the manubrium medially, thus tensing the tympanic membrane $[2,13,14]$.

\section{The middle ear spaces:}

The tympanic cavity is a cleft in the sagittal plane measuring about $15 \mathrm{~mm}$ in the vertical and anteroposterior dimensions. In its transverse dimension, it expands superiorly to $6 \mathrm{~mm}$ and inferiorly to $4 \mathrm{~mm}$ from a central constriction of $2 \mathrm{~mm}$. At the floor of the tympanic cavity (jugular wall) a small plate of bone separates the jugular bulb. In the posterior wall, the chordal eminence is lateral to the pyramidal eminence and medial to the posterior rim of the tympanic membrane. There is a foramen in this eminence, known as the iter chordae posterius, through which the chorda tympani nerve gains access to the middle ear. The facial recess is interposed between the chordal eminence laterally and the pyramidal eminence medially and superiorly bounded by the fossa incudis.
The sinus tympani lies between the ponticulus (which bridges the gap between the pyramidal eminence and the promontory superiorly) and the subiculum. The anterior wall of the middle ear (carotid wall) narrows inferiorly where it is formed by the thin bony shell of the carotid canal. Located more superiorly in the anterior wall is the orifice of the eustachian tube and above it the tensor tympani muscle lies in its semicanal.

The roof (tegmental wall, tegmen tympani) separates the tympanic cavity from the middle cranial fossa. The lateral boundary (membranous wall) is composed of the tympanic membrane, the bony tympanic ring, and a layer of bone from the squama - the scutum or shield of Leidy. The medial wall (labyrinthine wall) of the tympanic cavity is marked by two main depressions:

- The round window niche

- The oval window niche

The round window niche is located anteroinferior to the subiculum and posteroinferior to the promontory. The latter structure is the bulge of the bone overlying the basal turn of the cochlea.

The oval window niche is anterosuperior to the ponticulus. Located posterosuperiorly is the prominence of the facial canal as it traverses the medial wall and then descends along the mastoid wall of the tympanic cavity.

The middle ear space is divided into four regions:

1. The mesotympanum (middle ear proper) is that area located medial to the tympanic membrane and the bony tympanic annulus.

2. The epitympanum is that area that lies medial to the pars flaccida and scutum.

3. The protympanum lies anterior to a frontal plane drawn through to the anterior margin of the tympanic annulus. It leads to the tympanic orifice of the eustachian tube.

4. The hypotympanum is that part of the middle ear located inferior to a horizontal plane through the most inferior part of the tympanic annulus.

\section{The Eustachian tube:}

The eustachian tube, a mucosally lined pathway between the nasopharynx and the middle ear, permits ventilation of the pneumatized spaces of the temporal bone while safeguarding against bacterial contamination of these spaces. The posterolateral one-third is bony while the anteromedial two-thirds is fibrocartilaginous; these two sections are joined at the tubal isthmus. The overall length of the eustachian tube in the adult is $36 \mathrm{~mm}$.

\section{The middle ear mucosa:}

In electron microscopic observations, Hentzer distinguished five types of cells in the middle ear mucosa:

1. Nonciliated without secretory granules

2. Nonciliated with secretory granules

\section{Volume 8 Issue 12, December 2019}




\section{International Journal of Science and Research (IJSR) \\ ISSN: 2319-7064}

ResearchGate Impact Factor (2018): 0.28 | SJIF (2018): 7.426

\section{Ciliated \\ 4. Intermediate \\ 5. Basal}

The mucosa of the middle ear represents a modified respiratory mucosa.

\section{The Mastoid region:}

At birth the mastoid has a single cavity consisting of the antrum and small adjacent mastoid. It occupies a superficial position and is surrounded by diploic bone. In adult life, the normal mastoid may be fully pneumatized, diploic, or sclerotic. The anterolateral portion of the mastoid arises from the squamous part of the temporal bone; the posteromedial portion, including the mastoid tip, arises from the petrous part. In most mastoids, the plane of junction of these two parts is marked internally by an incomplete plate of bone, the petrosquamosal septum, also known as Koerner's septum. The mastoid antrum area is a large superior central space which communicates with the epitympanic space of the middle ear via the aditus [15, 16].

\section{The inner ear}

\section{The bony labyrinth:}

The long axis of the bony labyrinth, measuring $20 \mathrm{~mm}$ in length, roughly parallels the posterior surface of the petrous pyramid. Its components are the vestibule, the semicircular canals, and the cochlea [17].

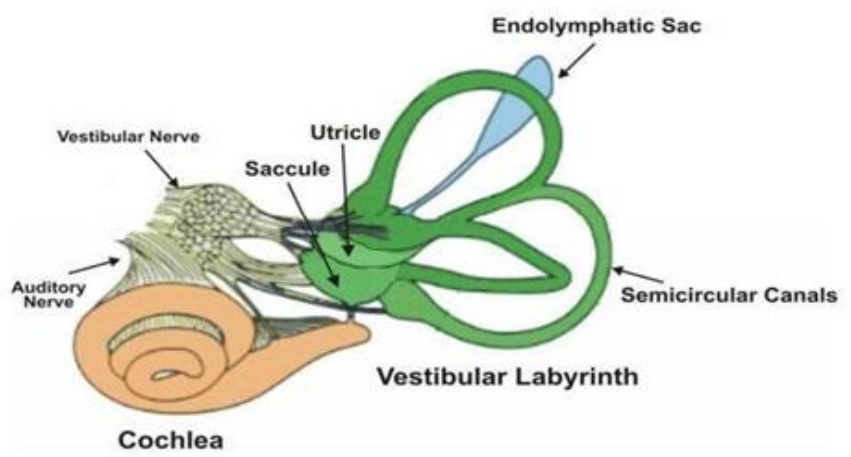

Figure 6: Inner ear [17]

The vestibule:

The vestibule is the central chamber. At the posterosuperior aspect of its medial wall is a depression known as the elliptical recess which accommodates part of the utricular macula. The spherical recess is a similar depression for the saccular macula, located anteroinferiorly. The vestibular crest is an oblique elevation between these two recesses. The opening for the cochlea lies anteriorly, while the openings for the semicircular canals are located posteriorly. The oval window is an opening on the lateral wall, adjoining the tympanic cavity. The vestibular aqueduct with its contained endolymphatic duct opens into the posteroinferior aspect of the vestibule [16].

\section{The canals:}

The osseous semicircular canals are:

\section{The lateral}

2.Posterior

3. Superior canals

Each canal expands to double its diameter at its osseous ampulla where it communicates with the vestibule. The non ampullated ends of the posterior and superior canals fuse, forming the common crus, while the non ampullated end of the lateral canal remains independent. Thus, the vestibule has five apertures for the semicircular canals.

\section{The membranous labyrinth:}

The membranous labyrinth is encased within the bony labyrinth and is surrounded by the perilymphatic space. The constituents are

1.The cochlear duct,

2.The three semicircular ducts and their ampullae,

3.The otolithic organs (the utricle and saccule), and the endolymphatic (otic) duct and sac.

This system of epithelially lined channels and spaces is filled with endolymph (Scarpa's fluid); the utricular duct, the saccular duct, and the ductus reuniens interconnect the major structures [18].

\section{Cochlea}

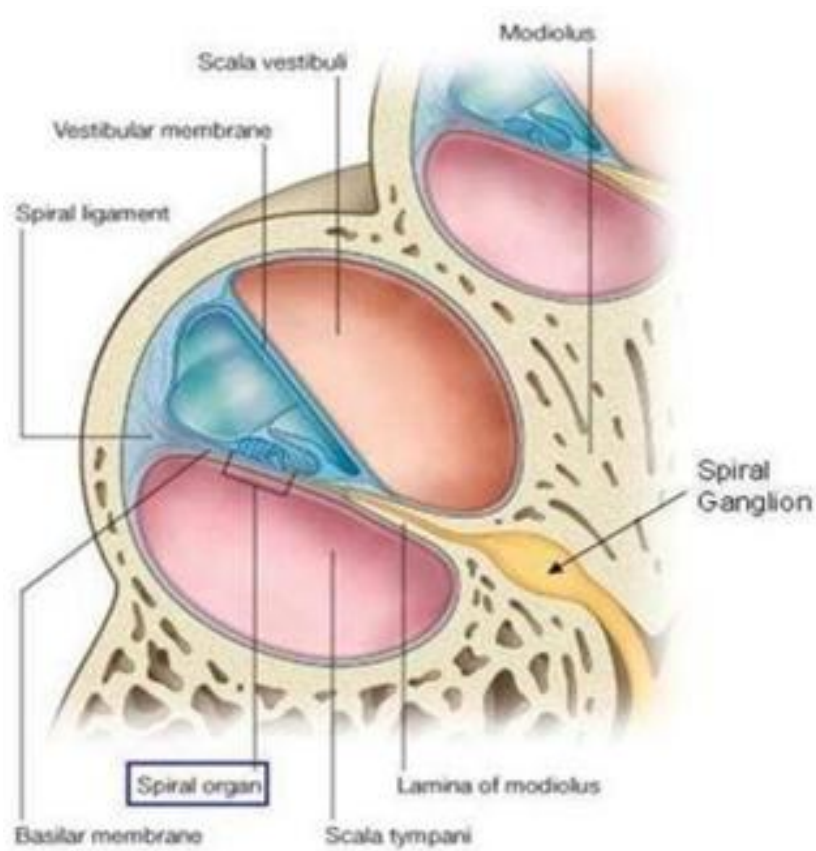

Figure 7: Cochlea [18]

The cochlea is snail shaped and has a spiral configuration with two and a half turns. The center portion of the spiral is called the modiolus. The portion of the cochlea that is closest to the oval window is the base, whereas the portion 


\section{International Journal of Science and Research (IJSR) \\ ISSN: 2319-7064}

ResearchGate Impact Factor (2018): 0.28 | SJIF (2018): 7.426

of the cochlea that is farthest away from the oval window is the apex.

The cochlea is having three compartments: scala tympani, scala vestibuli and scala media. The basilar membrane separates the scala tympani and the scala media, Reissner's membrane separates the scala media and the scala vestibuli The scala tympani and the scala vestibuli communicates with each other at helicotrema. In the scala media, the organ of Corti rests on the basilar membrane. Basilar membrane and organ of Corti are referred to as the cochlear partition. The organ of Corti has the inner and the outer hair cells. The inner hair cells are arranged in a single row and outer hair cells are arranged in three rows. These hair cells have hair like projections called stereocilia, which is responsible for the signal transduction in hair cells. The scala vestibuli and the scala tympani are filled with perilymph, which resemble the extracellular fluid (high in sodium, low in potassium) in composition. The scala media filled with end lymph, which resemble intracellular fluid (low in sodium, high in potassium) in composition. The electrolyte composition of the scala media causes the endocochlear potential, which is +60 to $+100 \mathrm{mV}$ relative to the perilymph [18].

\section{Physiology}

The difference between the impedance of air and the impedance of fluid is great; thus, in the transmission of sound energy from Air to Fluid medium, there would be a 99.9\% loss which is approximately $30 \mathrm{~dB}$ loss. The above loss can be overcome by impedence matching, which allows optimum sound energy transmission [19].

\section{Hydraulic lever}

This is the ratio of the surface area of the tympanic membrane to that of the oval window. The tympanic membrane surface area is $55 \mathrm{~mm} 2$ and stapes foot plate surface area $3.2 \mathrm{~mm} 2$. This difference represents a 17 -fold increase in surface area. Sound energy striking the much larger tympanic membrane is transmitted through to a much smaller surface area of the stapes footplate.

\section{Lever ratio}

The length of the manubrium, when compared the long process of the incus, is 1.3times longer. Hence the leverage gain is 1.3. Combined effects of these two mechanisms, the Hydrualic ratio and the lever ratio, the approximate gain is $22 \mathrm{~dB}$.

The two factors help in the transmission of sound energy are

1.Optimal Eustachian tube Function

2.Gas exchange within the middle ear Mucosa

\section{Eustachian tube}

The Eustachian tube has cartilaginous and bony portion. The lateral bony portion of the canal opens in the anterior wall of Middle Ear. The medial cartilaginous part, opens into the nasopharynx and is closed at rest. The tensor veli palatini opens the Eustachian tube orifice during swallowing, for a transient period that lasts $0.3-0.5 \mathrm{~s}$. This results in pressure equalization with the atmospheric pressure.

\section{Middle ear mucosal gas exchange}

Middle ear mucosa has a well-developed capillary structure close to its surface. This helps in gas exchange In normal conditions middle ear pressure is equal to atmospheric pressure, approximately $760 \mathrm{mmHg}$ at sea level. These gases are bi-directionally exchanged. Nitrogen gas level in middle ear is higher than that of venous blood. This gradient results in gas exchange between the middle ear space and venous blood. The absorption of nitrogen into the venous blood results in negative pressure in the middle ear. This is equalized by opening of the Eustachian tube. Prolonged Eustachian tube dysfunction hampers this mechanism results in negative middle ear pressure, transudation of fluid, and the development of a middle ear effusion and increases the middle ear acoustic impedence.

\section{Transmission of sound energy in the Cochlea}

When sound energy travels through the ear, it causes the stapes footplate to vibrate. The vibration of the stapes footplate produces a compressional wave in the perilymph, which travels to the scala vestibuli, through the helicotrema, and out across the scala tympani towards the round window. An inward motion of the stapes results in outward movement of the round window. When the organ of corti and basilar membrane are deflected in response to the compression wave, it produces a shearing force between the tectorial membrane and the stereocilia of the hair cells. This shearing force produces a deflection of stereocilia toward the direction of tallest row results in opening of stretch- sensitive cationic channels located on the stereocilia. The opening of these stretch- sensitive cationic channels causes a influx of cationic current, which results in hair cell depolarization.

When inner hair cells are depolarized, it opens voltagegated calcium channels. The resulting calcium current triggers neurotransmitter release across the synapse, which results in activation of the auditory nerve fibers [16, 19].

\section{Tympanoplasty - An overview}

Tympanoplasty (TM) is the procedure of removal of disease from the middle ear and reconstruction of the hearing mechanism along with TM grafting.

\section{History of Tympanoplasty:}

\section{0-Banzer}

- First attempt at repair of TM

- Used pigs bladder as a lateral graft

\section{Volume 8 Issue 12, December 2019}




\section{3-Toynbee}

- Placed a rubber disc attached to a silver wire over the TM

- Reported significant hearing improvement

\section{3-Yearsley}

- Placed a cotton ball over a perforation

\section{7-Blake}

- Paper patch

\section{6-Roosa}

- Chemical cautery

\section{8-Berthold}

- Coined the term Myringoplasty

\section{0-Wullstein and Zollner}

- Described 5 types of Tympanoplasty

\section{0-Heerman}

- First used temporalis fascia grafting material in tympanoplasty.

\section{1-Storrs}

- Temporalis fascia grafting

\section{7-House Glasscock and Sheehy}

- Techniques for lateral grafting

Indications for surgery:

1. Conductive hearing loss due to TM perforation or ossicular dysfunction

2. Chronic or recurrent otitis media secondary to contamination

3. Progressive hearing loss due to chronic middle ear pathology

\section{Contraindications for surgery:}

1. Malignant tumours

2. Unusual infections like malignant otitis externa.

3. Intracranial complications

4. Cholesteatoma

\section{Goals of the surgery:}

1.Establish an intact TM
2. Eradicate middle ear disease and create an air containing middle ear space

3. Restore hearing by sound pressure transformation between the eardrum and the cochlea

Techniques:-

\section{Overlay (lateral grafting)}

Overlay - Surface epithelium was removed around the perforation site and graft was put on the fibrous layer of TM [1].

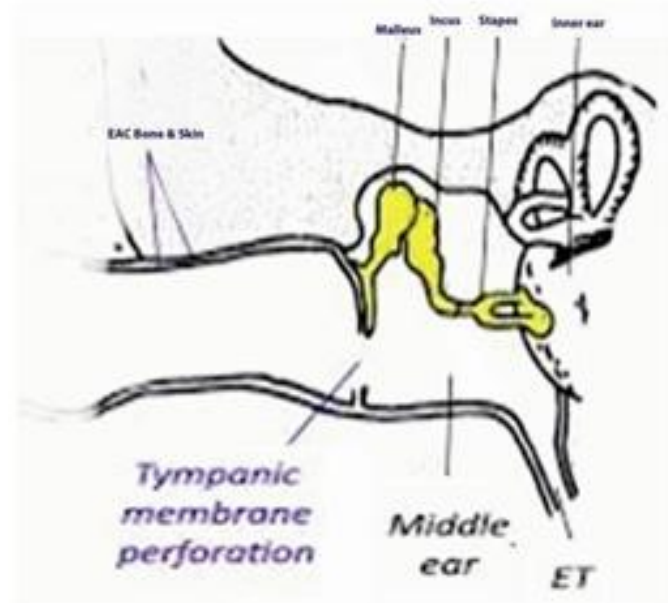

Figure 8: Tympanoplasty (Tympanic membrane perforation) [20]

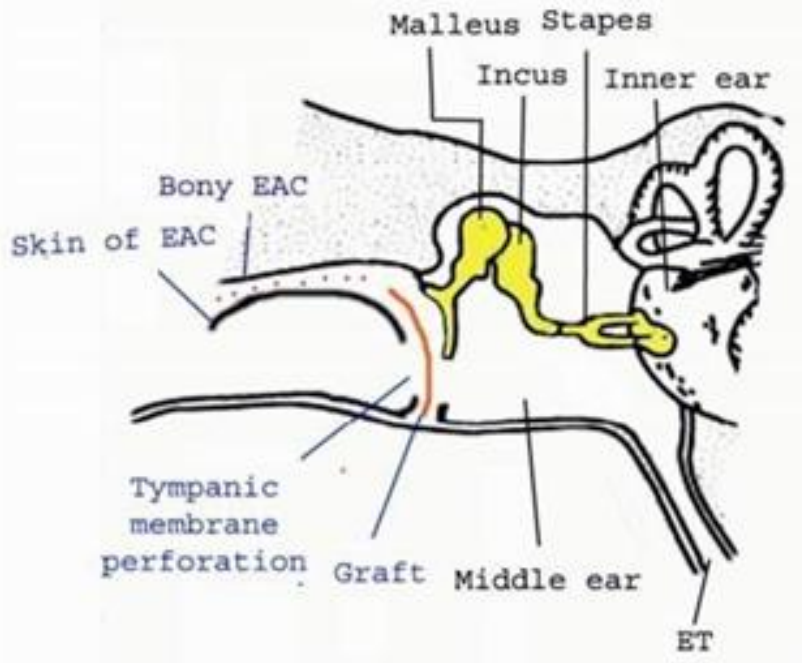

Figure 9: Tympanoplasty (Graft insertion) [21]

Over lay grafting Advantages:

1. Graft remains vascularised

2. Exposure of anteriormeatal recess

3. Middle ear space not reduced

\section{Disadvantages:}

1. Lateralisation of the graft

2. Blunting of anterior meatal recess

Volume 8 Issue 12, December 2019 www.ijsr.net 


\section{International Journal of Science and Research (IJSR) \\ ISSN: 2319-7064}

ResearchGate Impact Factor (2018): 0.28 | SJIF (2018): 7.426

3. Chance of iatrogenic cholesteatoma formation Healing may take longer (4-8 weeks)

1.Technically more demanding

2.Formation of epithelial pearl

\section{Underlay (Medial grafting)}

Underlay technique was introduced by SHEA. The graft was placed medial to the handle of malleus and TM remnant.

ADVANTAGES:

1. Less blunting or lateralisation

2. High graft uptake

\section{Disadvantages:}

1. Limited visualization of anterior meatal recess

2. Difficult with small EAC.

3. Less suitable in large anterior perforation

4. Reduction in middle ear space TM grafts

Histologically TM grafts become lined by squamous epithelium on the ear canal side and the middle ear mucosa on the tympanic cavity side [22].

\section{Grafting materials}

1. Temporalis fascia graft

2. Cartilage graft

3. Fat graft

4. Hyaluronic acid fat graft

5. Tragal perichondrium and cartilage

6. Vein graft

7. Conchal cartilage

8. Fascia lata

9. Subcutaneous tissue

10. Periosteum

\section{Approach}

\section{Transcanal}

Posterior moderate sized perforations Favourable EAC anatomy.

\section{Endaural}

Visualisation of annulus and anterior sulcus is difficult.

\section{Postaural}

All perforation sizes

Better angle of visualization

\section{Various surgical techniques}

1. Overlay-underlay technique

2. Combined technique

Two grafts-one under the handle of malleus Second on the fibrous layer of tm

3. Circumferential sub annular graft technique

4. Swing door technique

5.Butterfly and palisade technique cartilage Tympanoplasty

6. Cartilage shield tympanoplasty

7. The button graft technique

8. Cartilage tympanoplasty with island technique

9. Endoscopic vs microscopic tympanoplaty [23].
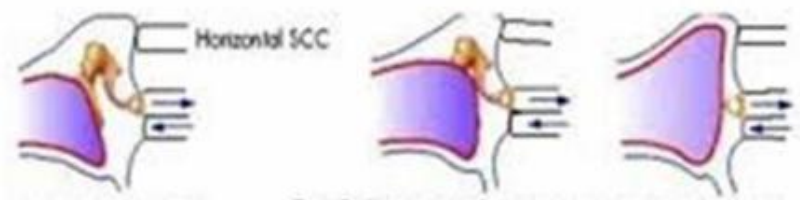

Jype 1: Kritgeplasty

Type 2: Mring inadopecy

Ifp3: Mprizp-stapetopec
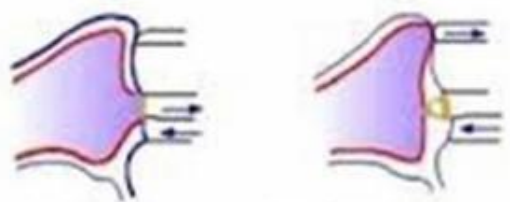

Tye 5 : fututrain

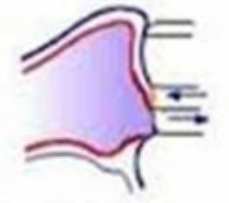

Iype 6: Semiturain

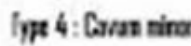

Figure 10: Classification of Tympanoplasty [24]
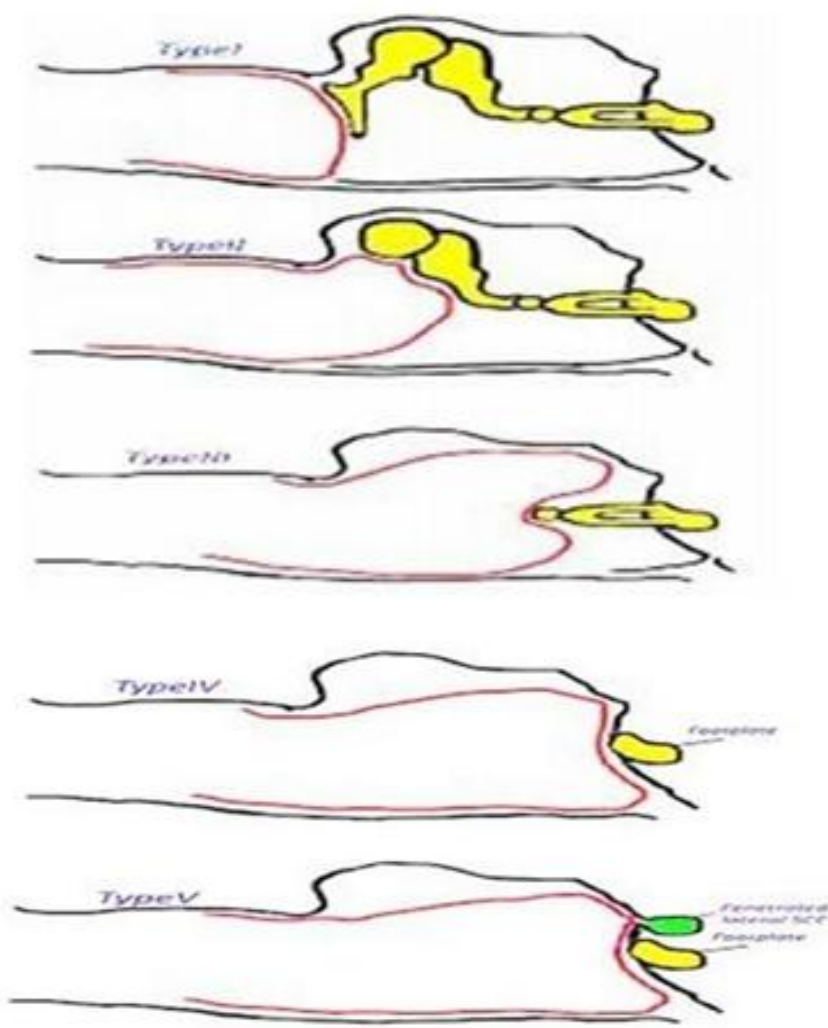

Figure 11: Wullstein classification of Tympanoplasty [25]

Volume 8 Issue 12, December 2019 www.ijsr.net 


\section{Wullstein and Zollner (1956): TYPE I}

TM is grafted to an intact ossicular chain

\section{TYPE II}

Malleus is partiallyeroded

TM is grafted to the long process of incus/ remaining malleus

\section{TYPE III}

Columella effect /Myringostapediopexy Malleus and incus are eroded

TM is grafted to the stapes suprastructure with cartilage in between

\section{TYPE - IV}

Stapes suprastructure is eroded but foot plate is mobile TM is grafted to a mobile footplate

Sound protection of the roundwindow and formation of airspace in the hypotympanum

\section{TYPE V}

TM is grafted to a fenestration in the lateral semicircular canal in cases with no ossicles and a fixed footplate.

In this thesis, study about the comparison of two different grafting materials were Temporalis fascia and Tragal perichondrium used in the patients undergoing type 1 tymnoplasty [25].

\section{Temporalis fascia:}

Temporalis fascia was first used in myringoplasty by Ortegtran (1958-59), Heerman (1961) and Storrs (1961). It is most commonly used autogenous material. It is preferred for various reasons:

1. It is easy to harvest.

2. It can be used asonlay, intermediate or underlay graft.

3 . For primary operation, there are no size limitations.

4. Fascia is quite similar to tympanic membrane with low basal metabolic rate.

5. For reconstruction of the tympanic cavity and ear canal, fascia is the only suitable autogenous material, because of its size.

\section{Tragal perichondrium:}

Tragal perichondrium was introduced into myringoplasty by Victor Goodhill et al (1964), after being used in stapedectomy as an oval window graft for some years before that. Like temporalis fascia, tragal perichondrium has several advantages:

1. It is easily accessible.

2. It is a mesodermal graft.
3. It has a good chance of postoperative survival.

4. It has a conical contour.

5. It is sufficiently large for myringoplasty of a total perforation [26].

\section{Clinical Review}

In 2013 Adip K. Shetty et al used tragal perichondrium as graft material in type 1 tympanoplasty with a success rate of $96 \%$ in the perichondrium group as compared with $92 \%$ in the control group. In perichondrium- cartilage group shows mean gain in AirBone gap was $16.5+7.27 \mathrm{~dB}$ as compared to $15+7.07 \mathrm{~dB}$ in temporalis fascia group. In this study there is no statistical significant difference in graft taken up and hearing gain between both groups [27].

In the study by M. Mohsen Wafaie et al in 2010 shows. Anatomical closure of TM perforations in $95 \%$ of patients in the cartilage group, and in $90 \%$ of patients in the temporalis fascia group with value $\mathrm{p}$ more than 0.05 . The mean acoustic gain in two group with no significant statistical difference [28].

R. K. Mundra et al (2013) did study. to evaluate the results of closure of subtotal perforation by tympanoplasty using underlay technique., with the perichondrium temporalis fascia graft supported by single sliced cartilage [29].

Emily Iacovou et al, 2012 to compare the hearing results., and graft take up rate in patients undergoing myringoplasty for the reconstruction of the tympanic membrane, with the use of cartilage or fascia temporalis. The mean graft uptake rate was $92.4 \%$ in the cartilage group and $84.3 \%$ in the fascia temporalis group. The obtained audiometric results are comparable to temporalis muscle facia group and the rate of reperforation is lower [30].

In 2011 Matthew Yung, Senthilnathan, Vivekanandan and Philip Smith study compares outcomes of myringoplasty procedures, using fascia and cartilage grafts. The graft integration of fascia and cartilage grafts at 24 months, were $84.2 \%$ and $80 \%$, respectively. The postoperative $\mathrm{AB}$ gaps and audiological gains at 24 months were $16.97 \mathrm{~dB}$ and $13.63 \mathrm{~dB}$, respectively, in the fascia group and $20.63 \mathrm{~dB}$ and $12.60 \mathrm{~dB}$ respectively in the cartilage group. There was no statistical significant difference, in the graft taken up or postoperative audiological gain between the two groups. In this study, they pointed out their limitation as very low sample size, so interpreted with caution [31]. In 2014 Rajeev Reddy conducted "study of results. of cartilage-perichondrium vs temporalis fascia grafting in chronic suppurative otitis media." temporalis fascia group showed a good neotympanum about 60 patients (84.5\%), 7 patient (9.85\%) had reperforation and $5(7.04 \%)$ had retraction pockets. About 60 (98.6\%) Patients showed a healed Tympanic membrane and only 1 (1.63\%) had reperforations in tragal cartilage perichondrium group. Patients with temporalis fascia graft showed an $\mathrm{AB}$ gap of less than $10 \mathrm{~dB}$ in $49(82 \%)$ patients and more than $10 \mathrm{~dB}$ in $11(18 \%)$ patients. AB gap closure with tragal cartilage 


\section{International Journal of Science and Research (IJSR) \\ ISSN: 2319-7064}

ResearchGate Impact Factor (2018): 0.28 | SJIF (2018): 7.426

perichondrium was less than $10 \mathrm{~dB}$ in $45(78 \%)$ patients and more than $10 \mathrm{~dB}$ in 13 patients (12\%). "Tragal cartilage perichondrium $(<0.5 \mathrm{~mm})$ seems to be an ideal graft material for tympanic membrane, in terms of postoperative healing and acoustic properties" [32].

In the study by Kazikdas et al, 2007 reported graft acceptance rate about $97.5 \%$ with palisade cartilage tympanoplasty, for the anatomical closure of subtotal perforations compare with $75 \%$ of the fascia group. Regarding acoustic gain, they found no statistical difference between cartilage and fascia groups [33].

Zahnert et al. (13) reported that the ideal acoustic thickness of cartilage should be approximately $0.5 \mathrm{~mm}$ instead.of full thickness of 0.7 to $1 \mathrm{~mm}$ to achieve better audiological outcome [34].

Yakup Yegi n et al between 2009 to 2014 .did comparative "study of temporalis muscle fascia and fullthickness cartilage grafts in type 1 tympanoplasty "in 247 patients. in the cartilage tympanoplasty patien.t show higher graft take rate $91.3 \%$ than fascia tympanoplasty patient $68.9 \%$ with $\mathrm{p}<0.001$, but audioulogical gain are not statistically significance, in with full thickness cartilage tympanoplasty.compare to fascia [35].

M M KHAN, S R PARAB conduct.study on sliced cartilage. and temporalis fascia myringoplasty. Period of study 2005-2008. On four year follow up anatomic closure of perforation $97.5 \%$. in cartilage group, and $82.63 \%$ in fascia group. Hearing gain comparable.on both group (average AirBone gap $7.10 \mathrm{~dB}$ in cartilage vs $8.05 \mathrm{db}$ in other group) [36].

In 2010 M. Mohsen, Wafaie Abdelaziz., M.Elsherif M. Salama Bakr were did study at ENT Dept. AL-Azhar university. They got $95 \%$ of tympanicmembrane closure in cartilage as compared to $90 \%$ fascia group. Audiological gain in. cartilage group was $12.4 \pm 6.4 \mathrm{~dB}$, and $14.8 \pm 9.9 \mathrm{~dB}$ in fascia group with no significant statistical difference between the two groups [37].

In 2016 Rahul K. Jaiswal did study. in Nepal 'Comparison of outcomes of palisade cartilage with temporalis fascia.following tympanoplasty”. 40 His study shows closure of $\mathrm{AB}$ gap within. $30 \mathrm{~dB}$ was achieved in $71.87 \%$ of temporalis fascia group and $88.89 \%$ in palisade cartilage group and anatomical closure. of perforation was comparable in both group [38].

In 2015 Sohil Vadiya et al study conducted in Gujarat to compare the outcome of cartilage shield tympanoplasty with TM fascia type 1 tympanoplasty in cartilage group.

Graft uptake about $98.46 \%$ as compare to 89.61 of TM fascia group. In this study graft uptake rate. show statistical significant in both group. And audiological improvement in both group almost equal except at $8 \mathrm{kHz}$ frequency where improvement in TM fascia group than cartilage group [39].
Uzun et al. achieved 100\%.graft up, take with type 1 palisade - cartilage grafting, whereas $84.2 \%$ only success rate was observed in temporalis fascia type 1 tympanoplasty [40].

In Korea LEE HY et al conducted. a study of change of middle ear mechanics after sliced cartilage type 1 tympanoplasty and compare with fascia tympanoplasty.43 Period of study. 2002 to 2005 and followed up after 6 month. They founded there was no statistical. significant between two group in impedance audiometry [41].

Cabra et al did at randomized. controlled trial between 1997 to 2002 in general hospital. They allocated 64 patient to cartilage group. and 59 patient into fascia temporalis, group. 1st they analyzed outcome after 24 month anatomical. success was $82.26 \%$ (51 of 64) in cartilage. tympanoplasty and $64.41 \%$ (38 of 58) in TM fascia group. The functional; outcome comparable. between both 2 groups [42].

Juveria Majeed, Naveed Ahamed, 2016 reported the patients with tubotympanic type of chronic suppurative otitis media were selected from all patients attending to the ENT department of Gandhi Hospital, Secunderabad between July 2014 to March 2016. This study includes 60 patients out of which 30 were subjected to myringoplasty with temporalis fascia and remaining 30 to myringoplasty with tragal perichondrium. In all patients, discharging ears and associated nasal pathologies were excluded. The comparative study was done on following parametersgraft uptake, audiological outcome, donor site complications and any late complications such as reperforation, retraction, worsening of hearing and adhesions. Our study included a follow up of post operative cases for 1 year 8 months. Out of 60 cases operated, 11 cases didn't come for follow up. Hence they were excluded. The remaining 49 cases were 25 temporalis fascia group and 24 tragal cartilage group. The youngest patient in our group was 13 years while the oldest was 56 years old. The overall male: female ratio was $27: 22$. The patients who underwent temporalis fascia grafting, $86.73 \%$ had a gain of $15 \mathrm{~dB}$ while $13.7 \%$ had a gain of $>15 \mathrm{~dB}$. Of the patients underwent tragal perichondrium grafting $50 \%$ had a gain of $15 \mathrm{~dB}$ while $10 \%$ had a gain of $>15 \mathrm{~dB}$. The graft uptake rate was $85.7 \%$ for both temporalis fascia as well as tragal perichondrium. $4 \%$ of the patients of the temporalis fascia group had seroma and $4 \%$ had persistantpain..Residual perforation was seen in 3 patients of temporalis fascia group and 4 patients of tragal perichondrium group. 1 case of each group showed canal stenosis [43].

\section{Methodology}

\section{Source of data}

A sample size of in age group of 18 to 60 years in CSOM cases were selected for the study. Duration of study 2 years i.e. from a total of 100 patients in age group of 18 to 60 years with CSOM tubo tympanic disease who underwent Type 1 tympanoplasty by underlay technique in the Department of ENT, Narayana Medical College \& 


\section{International Journal of Science and Research (IJSR) \\ ISSN: 2319-7064}

ResearchGate Impact Factor (2018): 0.28 | SJIF (2018): 7.426

Hospital were studied in the period of two years. (Between October 2017 to September 2019).

\section{Inclusion criteria}

1. Patient with CSOM (Tubotympanic) with a hearing loss upto $45 \mathrm{~dB}$

2. Patient in the age group of $17-60$ years of either sex were selected for the study.

\section{Exclusion criteria}

1. Patients with active discharge.

2. Patients with attic disease.

3. Patients with systemic diseases like diabetest Hyper tension, Ischemic Heart disease.

All the patients who presented with symptoms and signs suggesting tubotympanic type CSOM were submitted to an assessment protocol, based on a guided history taking, specific physical exam (otoscopy), and subjected to audiogram. During history taking, the patients were questioned about disease onset, and if they had undergone previous otologic surgeries.

A detailed proforma was filled for each patient with regard to history, clinical examination, investigations, surgical procedures, postoperative period \&follow up visits. Audiological evaluation (pure tone audiometry) done preoperatively, 1 month \& 3 months after surgery and the results were tabulated.

Pure tone threshold audiometry has become the standard behavioral procedure for describing audiometry sensitivity. Therefore pure tone audiometry had been used for assessment of hearing level in this study.

The Audiometer (Elcon 3N3 Multi) used in this study was manual.

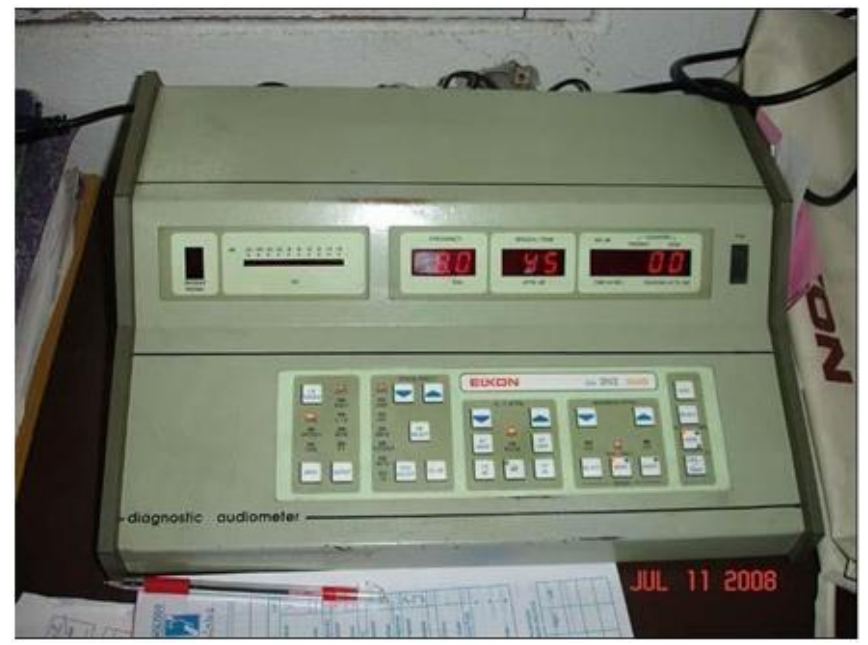

Figure 12: Audiometer (Elcon 3N3 Multi)

The test was performed in acoustically treated room with no ambience noise the audiometry was done following standard protocol. Patient was explained about the procedure before audiometry and adequate time was taken for testing. The technique followed was Carhart \& Jerger's technique which is mostly used (technique of 5 up and 10 down method).

For calculation of average of hearing loss (air conduction threshold) three frequencies were selected. They were 500 $\mathrm{Hz}, 1000 \mathrm{~Hz}$ and $2000 \mathrm{~Hz}$. These frequencies were selected because they represent speech frequency range and elevation of threshold in these frequencies will be clinically significant.

All surgeries were performed under local or general anesthesia using a microscope with a lens of $250 \mathrm{~mm}$. In most of the cases postauricular approach was used. In cases where the external acoustic meatus was wide and the perforation borders were visible endaural or transcanal approach was performed. Temporalis fascias, Tragal perichondrium, were taken as graft materials for cases and underlay grafting done in all cases.

All the patients were followed after surgery every week for 1 month but the puretone audiograms were done at 1 month and 3 month postoperativerly

\section{Graft materials used for the procedure were}

Autologous temporalis fascia

Autologous tragal perichondrium

\section{Temporalis fascia:}

Temporalis fascia was obtained during the surgical procedure. In cases using post- auricular incision \& endaural incision as shown in the figure $16 \& 17$ respectively. The same incision was extended to harvest the temporalis fascia. In transcanal surgeries, a separate transverse incision was placed above the pinna on the temporal region to obtain a graft from temporalis fascia or over tragus (Figure 18) to obtain perichondrium and cartilage. After obtaining the graft, it was spread on to a graft spreader and teased to remove excessive muscle fibres; fat and fibrous tissues so that it appears like parchment when dry (Figure 19). The temporalis fascia graft is seen after one month and three months of tympanoplasty as shown in figure 20 and 21 respectively.

Autologous tragal perichondrium: It was obtained during the surgical procedure from the tragal cartilage is as shown in the figure. 
International Journal of Science and Research (IJSR)

ISSN: 2319-7064

ResearchGate Impact Factor (2018): 0.28 | SJIF (2018): 7.426

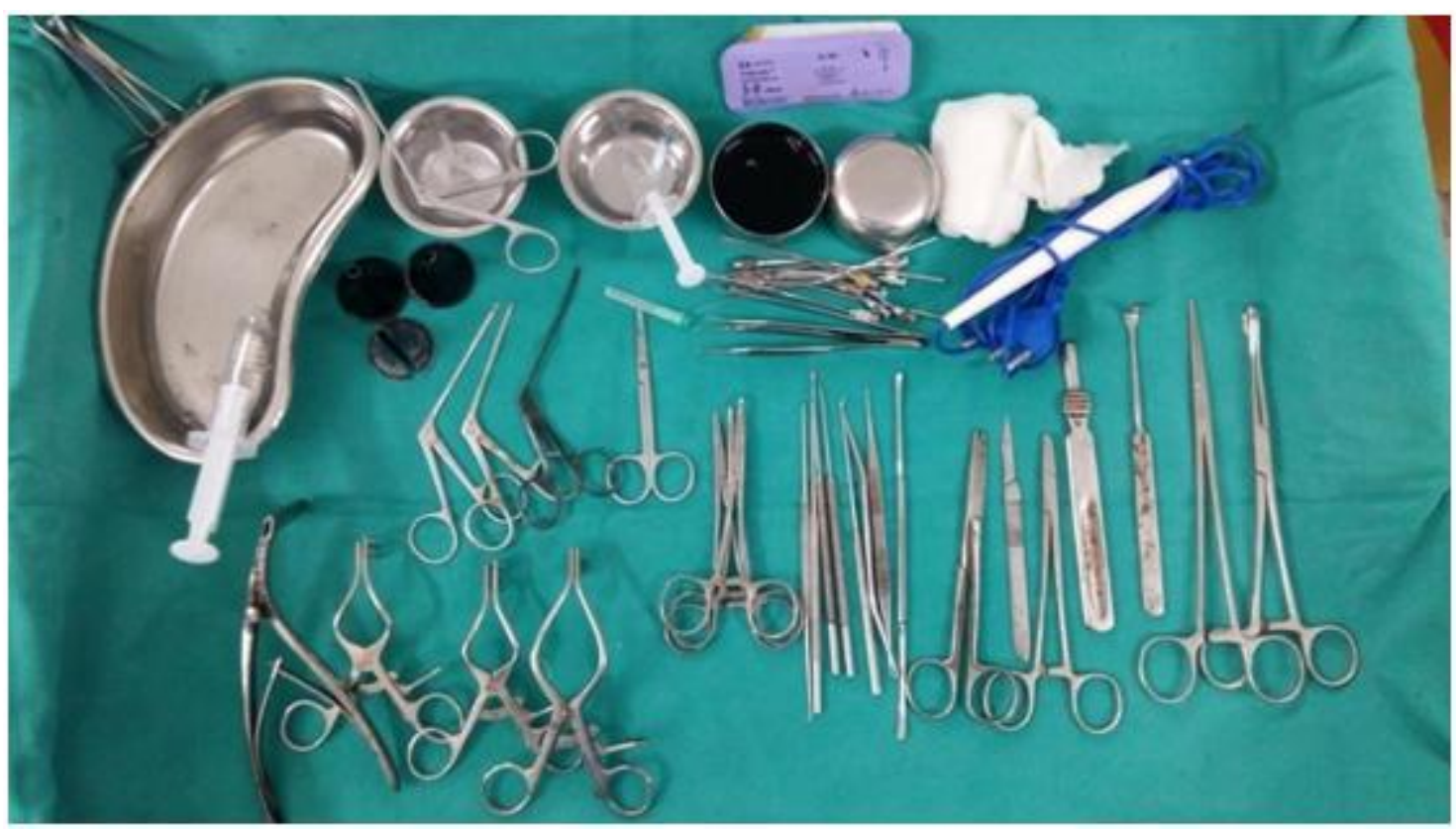

Figure 13: Tympanoplasty instrument set

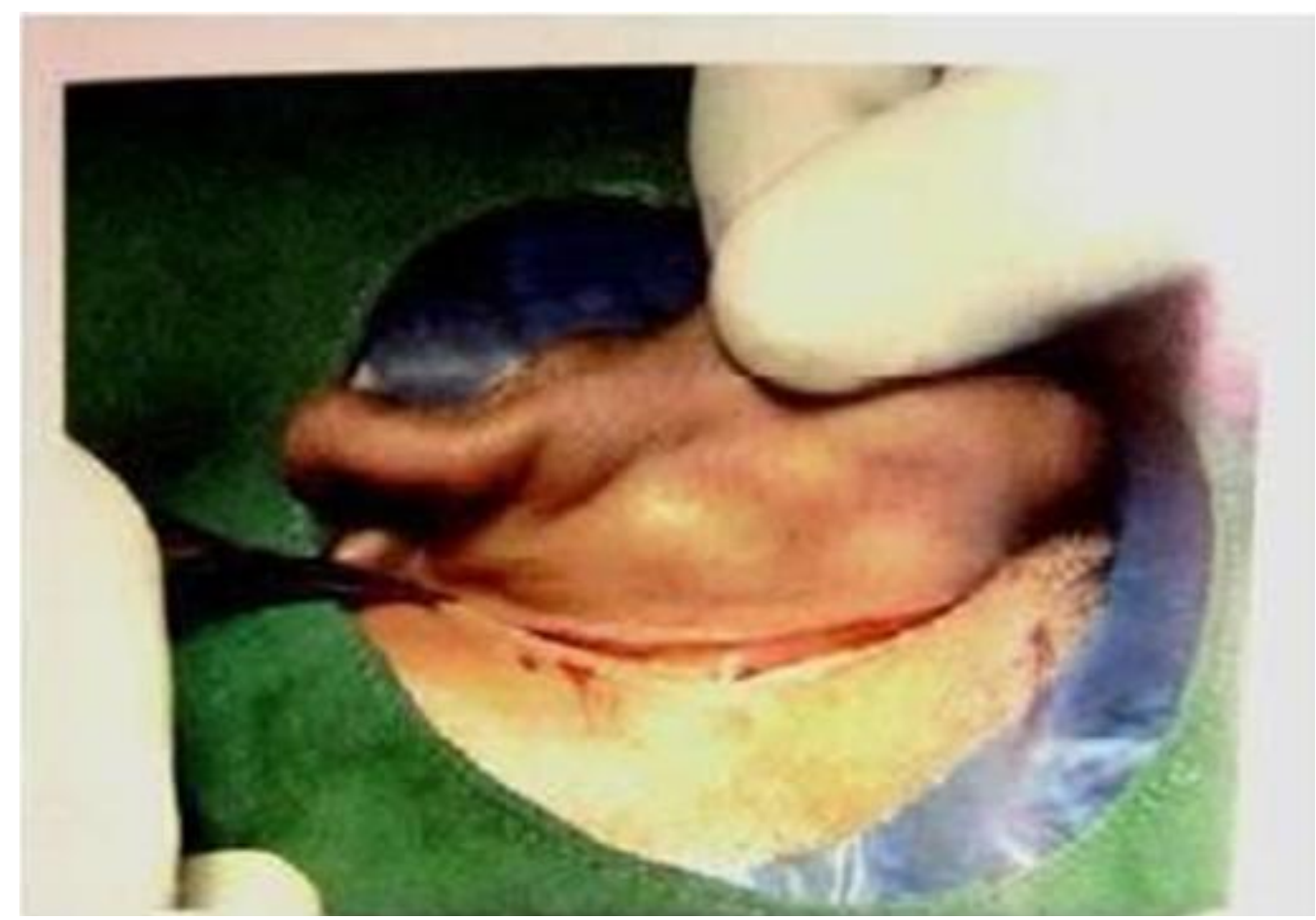

Figure 14: Post aural incision

Volume 8 Issue 12, December 2019

www.ijsr.net

Licensed Under Creative Commons Attribution CC BY 
International Journal of Science and Research (IJSR)

ISSN: 2319-7064

ResearchGate Impact Factor (2018): 0.28 | SJIF (2018): 7.426

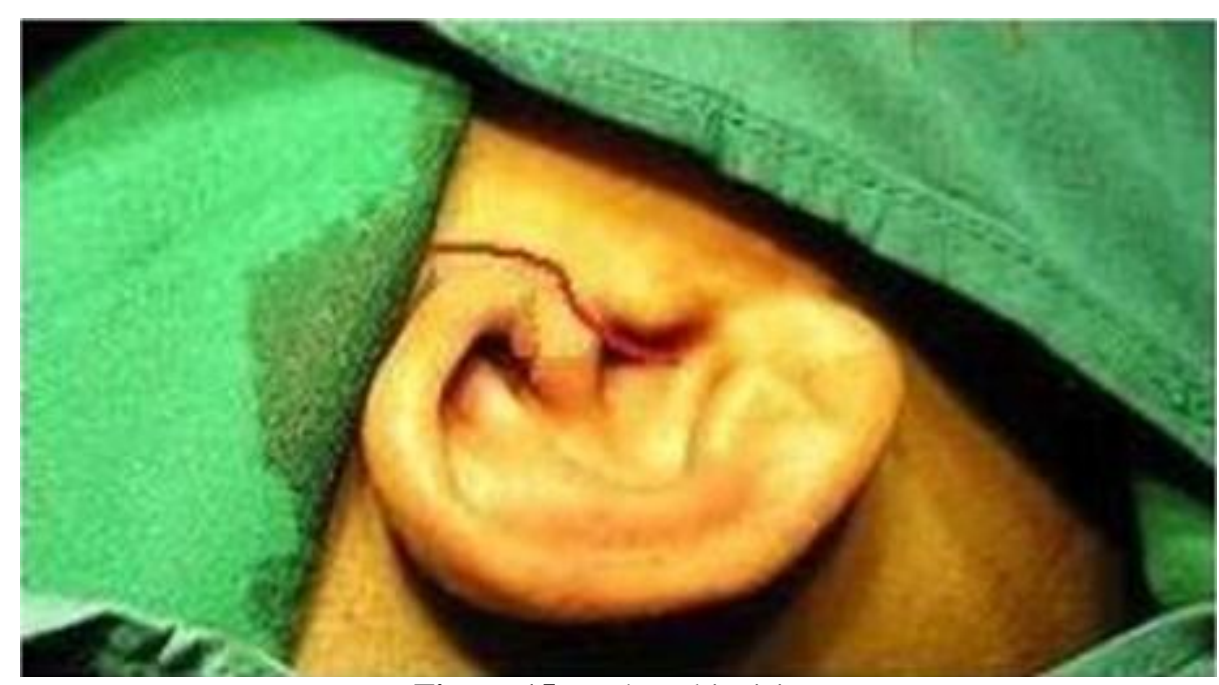

Figure 15: Endaural incision

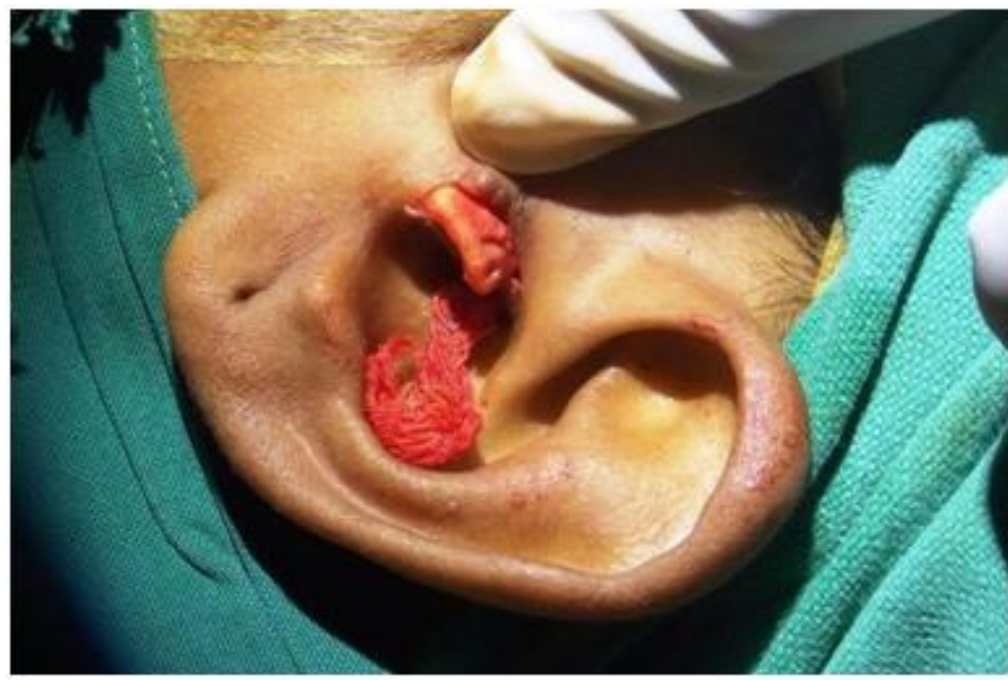

Figure 16: Transcanal approach with tragal perichondrium as graft

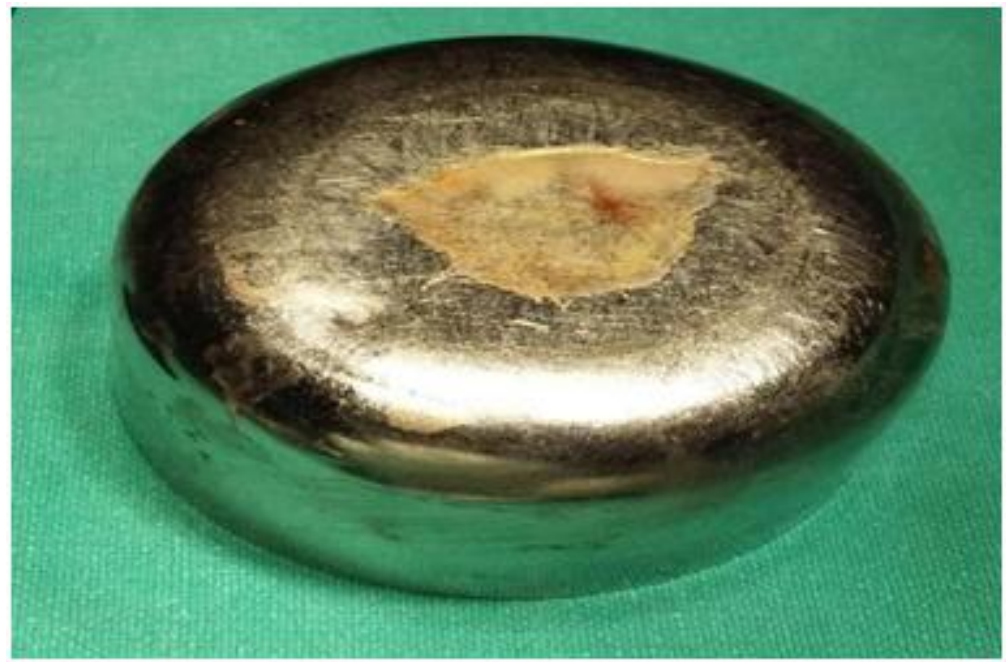

Figure 17: Prepared temporalis fascia

Volume 8 Issue 12, December 2019 www.ijsr.net

Licensed Under Creative Commons Attribution CC BY 


\section{International Journal of Science and Research (IJSR)}

ISSN: 2319-7064

ResearchGate Impact Factor (2018): 0.28 | SJIF (2018): 7.426

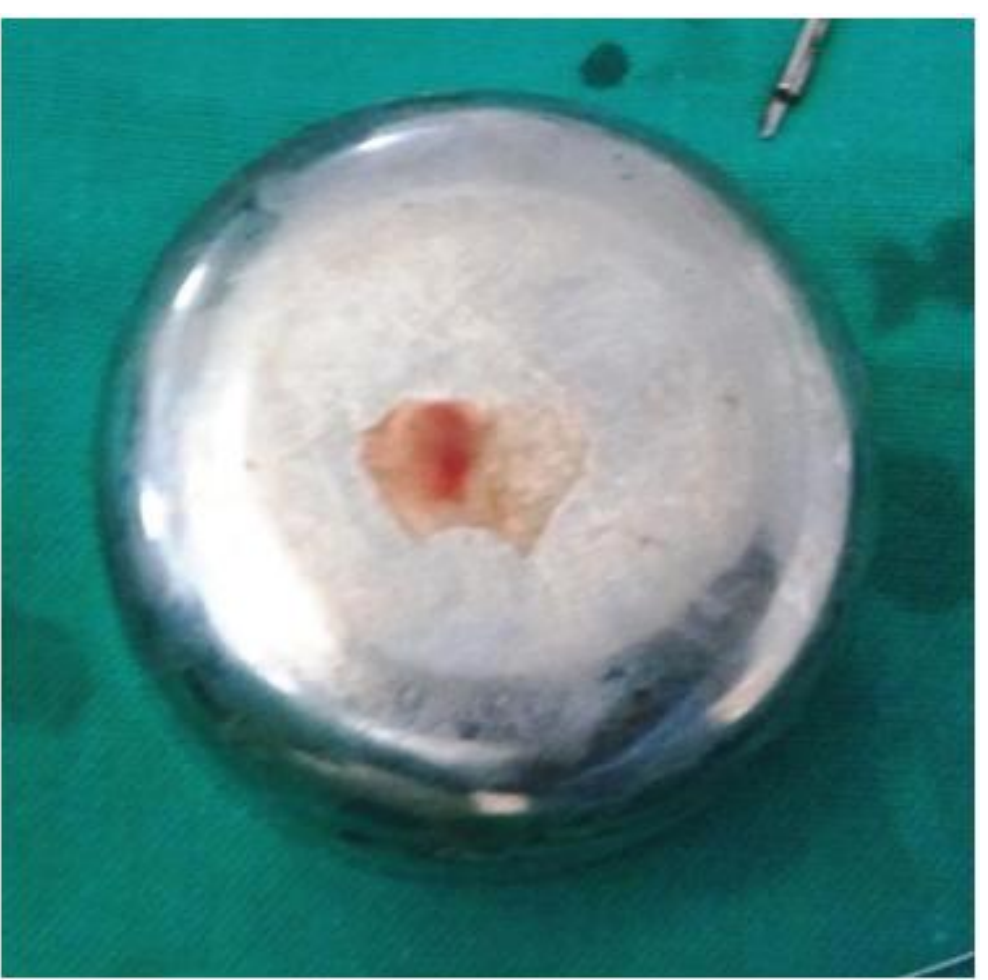

Figure 18: Tragal perichondrium

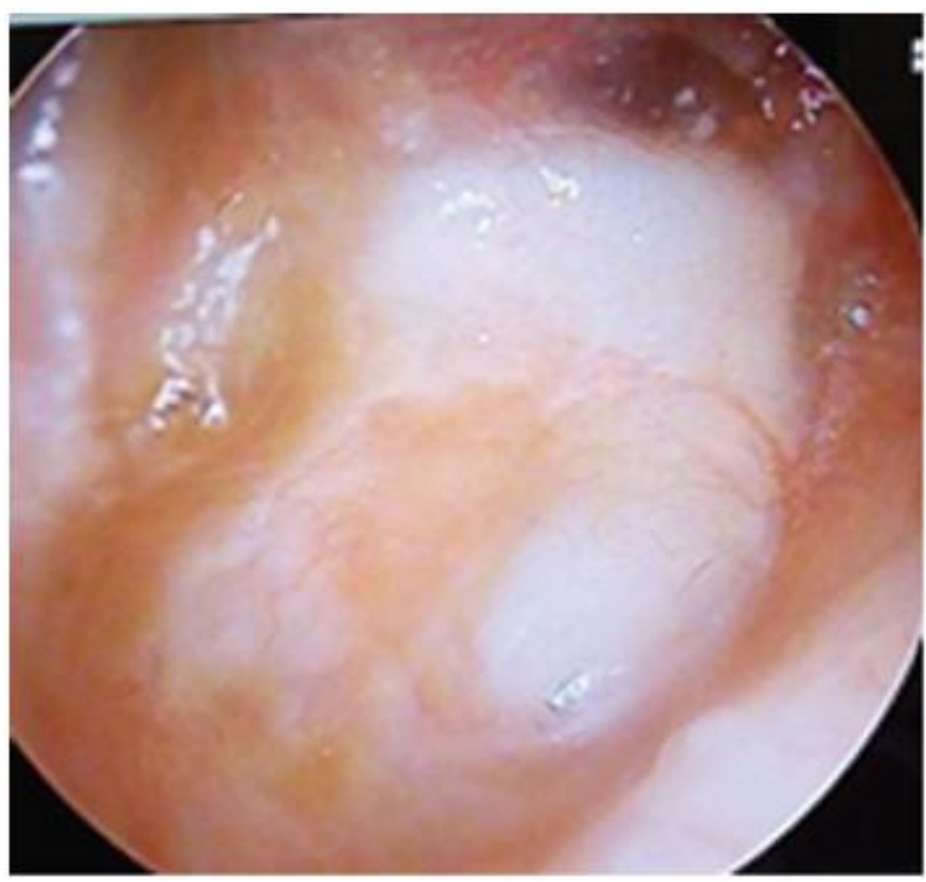

Figure 19: Temporalis fascia graft-1 month post tympanoplasty

Volume 8 Issue 12, December 2019 www.ijsr.net 


\section{International Journal of Science and Research (IJSR) \\ ISSN: 2319-7064}

ResearchGate Impact Factor (2018): 0.28 | SJIF (2018): 7.426

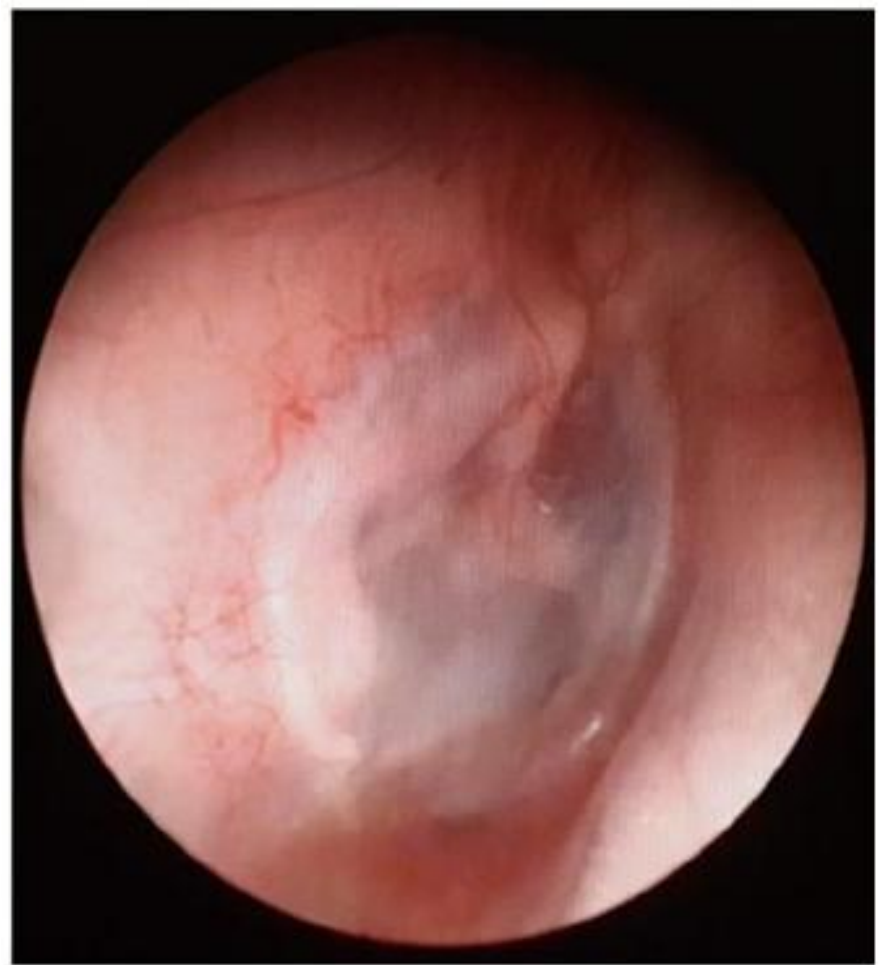

Figure 20: Temporalis fascia graft-3 months post tympanoplasty

\section{Results and Observations}

In our series we studied 100 ears (100 patients) of type 1 Tympanoplasties. The age and sex incidence and various factors influencing the audiological benefit in a successful type 1 tympanoplasty were analysed after 1 month and 3 months and the results were analysed based on the observations of the second follow up Pure tone audiograms (after 6 months).

Table 1: Age distribution of patients

\begin{tabular}{|c|c|c|}
\hline Age (in years) & No. of patients & Percentage \\
\hline $15-20$ & 22 & $22 \%$ \\
\hline $21-30$ & 42 & $42 \%$ \\
\hline $31-40$ & 18 & $18 \%$ \\
\hline $41-50$ & 15 & $15 \%$ \\
\hline $51-60$ & 3 & $3 \%$ \\
\hline Total & $\mathbf{1 0 0}$ & $\mathbf{1 0 0 . 0 0 \%}$ \\
\hline
\end{tabular}

Patients under 15 years of age were not included in this study. In this study maximum numbers of patients were seen in the age group of $21-30$ years $(42 \%)$

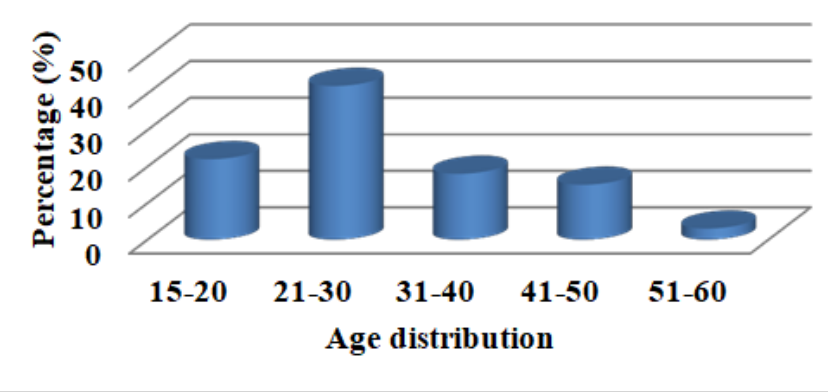

Figure 1: Age distribution of patients
Table 2: Age factor and audiological improvement

\begin{tabular}{|c|c|c|}
\hline Age (in years) & $\begin{array}{c}\text { No. } \\
\text { of cases }\end{array}$ & $\begin{array}{c}\text { Average } \\
\text { audiological gain }\end{array}$ \\
\hline $\begin{array}{c}15-40 \\
\text { years }\end{array}$ & 82 & $9.67 \mathrm{~dB}$ \\
\hline Above 40 years & 18 & $9.45 \mathrm{~dB}$ \\
\hline Total & $\mathbf{1 0 0}$ & \\
\hline
\end{tabular}

In our series, 18 tympanoplasties were performed in patients aged over 40 years. The average audiological gain was found to be lower in these patients $(9.45 \mathrm{~dB})$ compared to that of the younger age group $82(9.67 \mathrm{~dB})$.

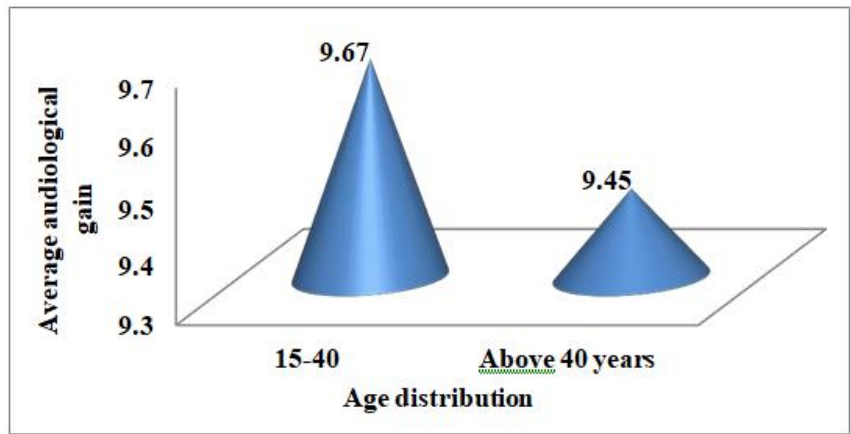

Graph 2: Age factor and audiological improvement

Table 3: Sex distribution of patients

\begin{tabular}{|c|c|c|}
\hline Sex & No. of patients & Percentage \\
\hline Males & 51 & $51 \%$ \\
\hline Females & 49 & $49 \%$ \\
\hline Total & $\mathbf{1 0 0}$ & $\mathbf{1 0 0 . 0 0 \%}$ \\
\hline
\end{tabular}

In our study, the sex distributions among patients were males $51(51 \%)$ than females $49(49 \%)$.

Volume 8 Issue 12, December 2019 www.ijsr.net 


\section{International Journal of Science and Research (IJSR) \\ ISSN: 2319-7064}

ResearchGate Impact Factor (2018): 0.28 | SJIF (2018): 7.426

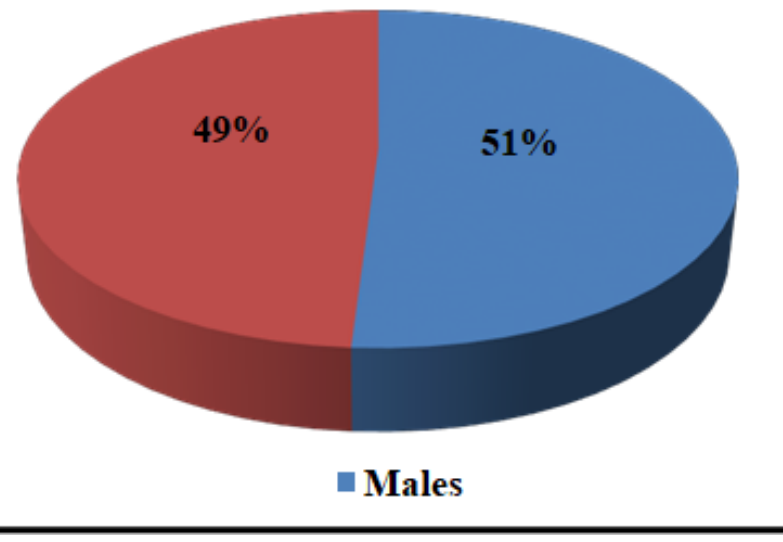

Figure 3: Pie chart of sex distribution of patients

Table 4: Sex incidence and audiological benefit

\begin{tabular}{|c|c|c|}
\hline Gender & $\begin{array}{c}\text { No. } \\
\text { of cases }\end{array}$ & $\begin{array}{c}\text { Average } \\
\text { audiological Gain }\end{array}$ \\
\hline Males & 51 & $9.48 \mathrm{~dB}$ \\
\hline Females & 49 & $9.83 \mathrm{~dB}$ \\
\hline Total & $\mathbf{1 0 0}$ & \\
\hline
\end{tabular}

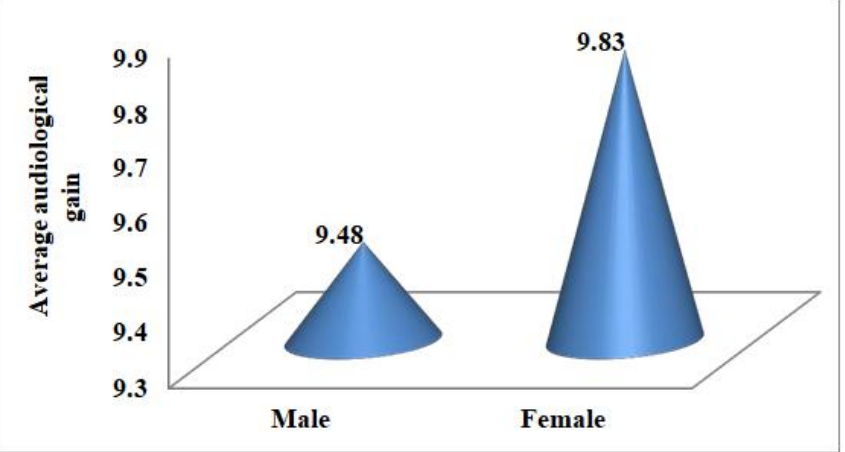

Figure 4: Graph of sex incidence and audiological benefit

In this study, the audiological benefit observed more in females could be an incidental finding as no reason could be attributed to this observation.

Table 5: Time taken for graft uptake and audiological

\begin{tabular}{|c|c|c|}
\hline \multicolumn{3}{|c|}{ benefit } \\
TIME (in & $\begin{array}{c}\text { No. } \\
\text { of cases }\end{array}$ & $\begin{array}{c}\text { Average } \\
\text { audiological gain }\end{array}$ \\
\hline 3 & 86 & $9.61 \mathrm{~dB}$ \\
\hline$>3$ & 14 & $9.93 \mathrm{~dB}$ \\
\hline Total & $\mathbf{1 0 0}$ & \\
\hline \multicolumn{3}{|c}{} \\
\hline
\end{tabular}

Audiological benefit was found to correlate with the time taken for graft take up, as the time taken for graft uptake increases, the hearing gain was found to decrease post operatively.

Table 6: Audiological assessment in Type-I tympanoplasty

\begin{tabular}{|c|c|}
\hline Hearing results & Audiological outcome \\
\hline Improved & $97(97 \%)$ \\
\hline No much change & $3(3 \%)$ \\
\hline Total cases & $\mathbf{1 0 0}$ \\
\hline
\end{tabular}

In our study of 100 cases, 97 (97\%) cases showed audiological improvement. There is no big difference of average audiological gain in rest of the cases.

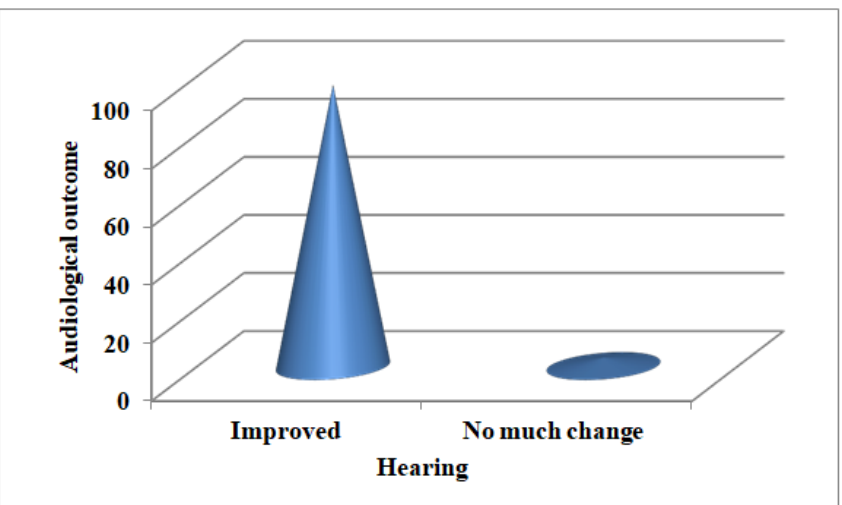

Figure 5: Pie chart of audiological assessment in Type-I tympanoplasty

Table 7: Effect of different grafts on audiological improvement in Type I tympanoplasty

\begin{tabular}{|c|c|c|}
\hline Type of graft & No. of cases & $\begin{array}{c}\text { Average audiological } \\
\text { gain }\end{array}$ \\
\hline Temporalis fascia & 47 & $10.07 \mathrm{~dB}$ \\
\hline Tragal perichondrium & 53 & $9.28 \mathrm{~dB}$ \\
\hline Total no. of cases & $\mathbf{1 0 0}$ & \\
\hline
\end{tabular}

The audiological improvement (average audiological gain) is more with temporalis fascia $(10.07 \mathrm{~dB})$ when compared to tragal perichondrium $(9.28 \mathrm{~dB})$.

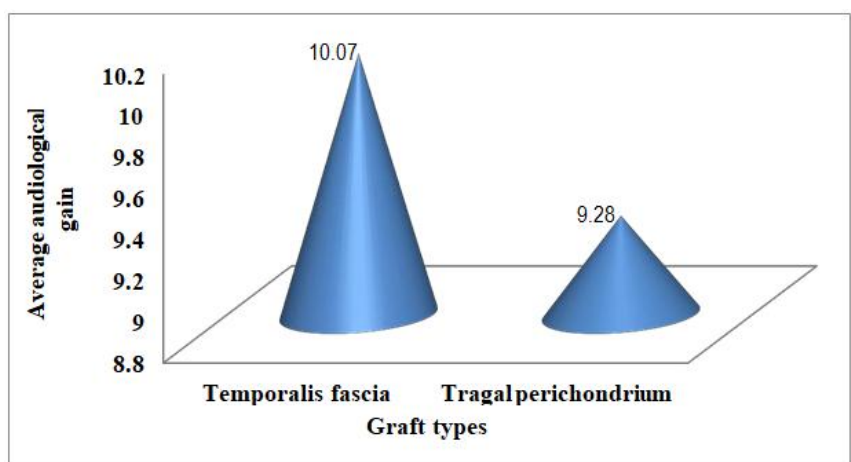

Graph 6: Effect of different grafts on auological improvement in Type I tympanoplasty

Table 8: Statistical analysis of different graft on audiological improvement in Type I tympanoplasty

\begin{tabular}{|c|c|c|c|c|c|c|}
\hline & & $\mathrm{N}$ & Mean & SD & F Value & P Value \\
\hline \multirow{3}{*}{$\begin{array}{l}\text { Preop } \\
\text { ave.AC } \\
\text { threshold } \\
\text { (dB) }\end{array}$} & TF & 47 & 31.03 & 3.44271 & \multirow{3}{*}{0.675} & \multirow{3}{*}{$\begin{array}{l}0.781 \\
\text { (Not } \\
\text { Sig.) }\end{array}$} \\
\hline & $\mathrm{TP}$ & 53 & 30.72 & 3.75556 & & \\
\hline & Total & 100 & 30.87 & 3.59723 & & \\
\hline \multirow{3}{*}{$\begin{array}{l}\text { Postop } 3 \\
\text { months } \\
\text { ave.AC } \\
\text { threshold } \\
\text { (dB) }\end{array}$} & TF & 47 & 20.96 & 2.56191 & \multirow{3}{*}{0.743} & \multirow{3}{*}{$\begin{array}{l}0.667 \\
\text { (Not } \\
\text { Sig.) }\end{array}$} \\
\hline & $\mathrm{TP}$ & 53 & 21.42 & 2.78343 & & \\
\hline & Total & 100 & 21.20 & 2.67800 & & \\
\hline \multirow{3}{*}{$\begin{array}{c}\text { Audiologica } \\
\text { gain }(\mathrm{dB})\end{array}$} & TF & 47 & 10.07 & 3.37184 & \multirow{3}{*}{1.553} & \multirow{3}{*}{$\begin{array}{l}0.161 \\
\text { (Not } \\
\text { Sig.) }\end{array}$} \\
\hline & TP & 53 & 9.28 & 2.85766 & & \\
\hline & Total & 100 & 9.65 & 3.16370 & & \\
\hline
\end{tabular}

Statistical analysis has been done by Annova test using IBM SPSS Version 22.0. $\mathrm{P}$ values which are less than 0.05 are considered as statistical significant. 


\section{International Journal of Science and Research (IJSR) \\ ISSN: 2319-7064}

ResearchGate Impact Factor (2018): 0.28 | SJIF (2018): 7.426

\section{Discussion}

Type I tympanoplasty is a surgical procedure in which the reconstruction procedure is limited to the repair of tympanic membrane perforation alone. Implicit definition is that the ossicular chain is intact and mobile, and that there is no middle ear disease such as infected mucosa or in growth of skin [1]. The present study describes various parameters in assessing the hearing improvement after tympanoplasty. Post operative audiological evaluations were done after 1 month and 3 months following type I tympanoplasty.

Table 9: Age Incidence

\begin{tabular}{|c|c|c|c|c|c|}
\hline \multicolumn{3}{|c|}{ Present study } & \multicolumn{3}{|c|}{ Ortegren [44] } \\
\hline $\begin{array}{c}\text { Age in } \\
\text { years }\end{array}$ & $\begin{array}{c}\text { No. of } \\
\text { patients }\end{array}$ & Percentage & $\begin{array}{c}\text { Age in } \\
\text { years }\end{array}$ & $\begin{array}{c}\text { No. of } \\
\text { patients }\end{array}$ & Percentage \\
\hline $0-10$ & 0 & 0 & $0-10$ & 5 & 5 \\
\hline $11-20$ & 22 & $22 \%$ & $11-20$ & 20 & 22.9 \\
\hline $21-30$ & 42 & $42 \%$ & $21-30$ & 13 & 14.9 \\
\hline $31-40$ & 18 & $18 \%$ & $31-40$ & 12 & 13.7 \\
\hline$>40$ & 18 & $18 \%$ & $>40$ & 37 & 42.5 \\
\hline Total & 100 & 100 & Total & 87 & 100 \\
\hline
\end{tabular}

Patients under 15 years of age are not included in this study. In this study maximum numbers of patients are seen in the age group of 21-30 years (42\%). This is in contrast to the study conducted by Ortergren, where the maximum number of the patients are in the age group of $>40$ years $(42.5 \%)$ [44].

Table 10: Age distribution in different studies

\begin{tabular}{|c|c|c|c|c|}
\hline Sl. No. & Author & $\begin{array}{c}\text { Year of } \\
\text { study }\end{array}$ & $\begin{array}{c}\text { Total no. } \\
\text { of cases }\end{array}$ & $\begin{array}{c}\text { Commonest } \\
\text { age group }\end{array}$ \\
\hline 1 & $\begin{array}{c}\text { Saha A K et al } \\
\text { [45] }\end{array}$ & 2006 & 40 & $14-34$ \\
\hline 2 & Fukuchi et al [46] & 2006 & 37 & $15-35$ \\
\hline 3 & Nagle et al [47] & 2009 & 100 & $21-30$ \\
\hline 4 & Goyal Rashmi [48 & 2010 & 80 & $11-40$ \\
\hline 5 & Present study & 2019 & 82 & $11-40$ \\
\hline
\end{tabular}

All the studies showed 15 - 40 yrs of age as the most common group and are correlating with the present study. The reason behind this may be that this is the socially active and health conscious age group.

Table 11: Age factor and audiological improvement

\begin{tabular}{|c|c|c|}
\hline Age (in years) & No. of cases & Audiological benefit \\
\hline $15-40$ years & 82 & $9.67 \mathrm{~dB}$ \\
\hline Above 40 years & 18 & $9.45 \mathrm{~dB}$ \\
\hline Total & 100 & \\
\hline
\end{tabular}

In our series, 18 tympanoplasties were performed in patients aged over 40 years. The audiological benefit was found to be lower in these patients $(9.45 \mathrm{~dB})$ compared to that of the younger age group $(9.67 \mathrm{~dB})$.

Ortegren has reported that there is a limit at 40 years beyond which hearing results are markedly worse than in younger cases. In Ortegren's study, the hearing improvement in the various groups below 40 years was obviously very much alike. Hearing results were worse in the above 40 years age group, compared to young age group. Vartiainen 10 et al found that results in elderly patients were found to be as good as in younger patients [44].

Table 12: Sex incidence and audiological benefit

\begin{tabular}{|c|c|c|}
\hline Age (in years) & No. of cases & Audiological benefit \\
\hline Males & 51 & $9.48 \mathrm{~dB}$ \\
\hline Females & 49 & $9.83 \mathrm{~dB}$ \\
\hline Total & 100 & \\
\hline
\end{tabular}

In this study, the audiological benefit observed more in males could be an incidental finding as no reason could be attributed to this observation.

Table 13: Graft taking time and audiological benefit

\begin{tabular}{|c|c|c|}
\hline Time (in weeks) & No. of cases & Audiological benefit \\
\hline $\mathbf{3}$ & 86 & $9.61 \mathrm{~dB}$ \\
\hline $\mathbf{3}$ & 14 & $9.93 \mathrm{~dB}$ \\
\hline Total & 100 & \\
\hline
\end{tabular}

In our study, the audiological benefit was found to correlate with graft take up time.

Akayleh R et al has similar outcomes as that of our study [49].

Table 14: Audiological assessment in tympanoplasty

\begin{tabular}{|c|c|}
\hline Hearing results & Audiological benefit \\
\hline Improvement & $97(97 \%)$ \\
\hline No change & $3(3 \%)$ \\
\hline Total & $100(100.00 \%)$ \\
\hline
\end{tabular}

In our study of 100 cases, $97(97 \%)$ cases showed audiological improvement. There is no big difference of average audiological gain in rest of the cases.

Table 15: Comparison of hearing improvement in various studies

\begin{tabular}{|c|c|c|}
\hline Sl.No & Study & $\begin{array}{c}\text { Hearing improvement } \\
(\% \text { of cases })\end{array}$ \\
\hline 1 & Saleem et al [50] & $\mathbf{8 5 . 8 8}$ \\
\hline 2 & Karela et al [51] & 91.5 \\
\hline 3 & Fukuchi et al $[46]$ & 92 \\
\hline 4 & Present study & 97 \\
\hline
\end{tabular}

The most likely explanation for lack of complete success from a hearing stand point is that in most cases of CSOM, even though ossicular chain may appear normal, there is some factor of scar tissue that prevents total restoration of hearing (Sheehy et al 1980). Sheehy has reported a loss of $\mathrm{BC}$ of $10 \mathrm{~dB}$ or more at $2 \mathrm{~K}$ or $4 \mathrm{~K}$ in $3 \%$ of cases, probably due to trauma to the ossicular chain [52].

Gibb \& Klat (1982) have also found that a persistent conductive hearing loss can result from underlay technique. If the handle of malleus is severely retracted especially if it is touching or adherent to the promontory, difficulties arise due to possible reduction in the depth of the tympanic cavity when the graft is placed medial to the malleus handle. To overcome this problem, they suggested that one could leave the malleus in its original retracted position and a split graft be pulled upon each size of 


\section{International Journal of Science and Research (IJSR) \\ ISSN: 2319-7064}

ResearchGate Impact Factor (2018): 0.28 | SJIF (2018): 7.426

malleus handle and tucked behind its upper part or amputate 2-3mm from the tip of handle [53].

Vartiainen and Nauutinene (1993) in their series had 11 audiological failures. The cause of persistent hearing loss was found to be due to fixation or erosion of ossicles overlooked by the surgeon [54].

Saeed Ghamdi et al 1994 reported a permanent hearing loss in $3 \%$ of the patients. Ghamdi also reported that one patient developed a profound SN hearing loss in the operated ear in his study. The unchanged audiological status in tympanoplasty can be explained by disorders that can interfere with the ventilatory or conducting function of the middle ear viz. tympanosclerosis, stiffness of ossicles and Eustachian tube dysfunction that have not been dealt during the surgery (Rance. W. Rancy in 1995) [55].

Alan G Gibb proposed the following reasons for worsening of hearing loss. They stated that a conductive loss can result from damage to the ossicular chain.

Sensorineural hearing loss appearing for the first time post operatively generally iatrogenic and the result of some technical error at operation. Thus it is essential to exercise extreme care throughout the operation and avoid undue commotion of ossicular chain which might cause cochlear damage [53].

If underlay grafting is employed, special care should be taken to avoid touching the incus or stapes when scarifying the postero superior are of the tympanic membrane remnant. If due care is not taken in this procedure it is possible to hook up the ossicles or incudostapedial joint with a scraper. It is also important to exercise extreme care when taking the graft into position in this area, as at this stage of operation, the ossicles are often obscured by the graft itself. In either event the stapes may be shaken and if the trauma is severe, the foot plate may even be cracked, sever or even total SN deafness may result.

The introduction of toxic solutions in the middle ear at the time of operation is another possible cause of SN deafness as previously reported by Alan G. Gibb et al [53].

Valsalva maneuver may add some audiological benefit when effectively incorporated which is supported by Seung Hyo Choi et al. The criteria of successful myringoplasty and tympanoplasty-1 surgery was a positive graft take and followed by improvement in hearing [56].

Table 16: Effect of different grafts on audiological improvement in Type I tympanoplasty

\begin{tabular}{|c|c|c|}
\hline Ear discharge & No. of cases & $\begin{array}{c}\text { Average audiological } \\
\text { gain }\end{array}$ \\
\hline Temporalis fascia & 47 & 10.07 \\
\hline Tragal perichondrium & 53 & 9.28 \\
\hline Total & 100 & \\
\hline
\end{tabular}

The average audiological gain is more with temporalis fascia (10.07) in the present study. Jain K, Pandey A, Gupta S, Rahul, 2016, did a clinical Study on hearing outcome after type 1 tympanoplasty using temporalis fascia as graft in 45 patients. They observed a mean hearing gain of $11.14 \mathrm{~dB}$ in their study [57].

According to study done by Lee et al., 2012, in a retrospective analysis of 40 patients with CSOM, compared the anatomical and audiological results of type I tympanoplasty using fascia temporalis, cartilage tissue, and cartilage palisade. No statistically significant differences were observed between the three groups regarding the closure of tympanic membrane perforations. Regarding auditory improvement, the cartilage palisade technique showed slightly poorer results than the others [58].

Ortegren during the period 1957 to 1961 did a comparison study of 87 patients of tympanoplasty-1 using temporalis fascia and canal skin graft. The relation of age on hearing and hearing results, importance of tubal function and causes of failures were discussed [44].

Palva et al in 1969 reported that they achieved a practically useful hearing ( 0 to $40 \mathrm{~dB}$, ISO standard) in $93 \%$ of cases postoperatively out of 160 myringoplasties. They used an operative method termed as 'swing door myringoplasty' [59].

In 1973, Glasscock analysed 237 myringoplasty cases using temporalis fascia. He found that the results were better using the underlay technique [60].

P. Packer et al, in 1982 compared preoperative and postoperative hearing evaluation in 604 patients. He also compared the different techniques and different graft materials used in his series [61].

G.S. Bawa et al in 1987 studied 50 cases of myringoplasties and showed a postoperative hearing improvement in $74 \%$ patients [62].

Sato H, Nakamura H, Honjo I, Hayashi M. in 1990 examined about the Prognostic value of preoperative Eustachian tube function in 77 ears, subjected to type 1 tympanoplasty. Eustachian tube function was evaluated by positive and negative pressure equalization tests, and clearance test and found that positive pressure equalization and clearance tests of the tube were correlated with the outcome of ear surgery, although the negative pressure equalization test had no correlation with it and concluded that the preoperative tubal function test including positive pressure test and clearance test are useful for predicting the prognosis of ear surgery [63].

Vartiainen et al in 1993 did a follow up study 404 cases of myringoplasties. In audiological failures the cause of persistent conductive hearing loss was found to be due to fixation or erosion of ossicles overlooked by the surgeon [64].

Kotecha B et al in 1999 presented a prospective audit study of myringoplasty.73 surgeons participated in this study and they got data from 1070 individual patients. Where hearing loss was the main indication for surgery, hearing improvement was seen in 67\% [65]. 


\section{International Journal of Science and Research (IJSR) \\ ISSN: 2319-7064}

ResearchGate Impact Factor (2018): 0.28 | SJIF (2018): 7.426

Mak D et al in 2000 January published a paper on a field assessment of the surgical outcome in middle ear disease in remote aboriginal Australia during the period 1986 to 1995.Success was defined by an intact tympanic membrane and air-bone gap of $25 \mathrm{~dB}$ at 6 month follow up after operation. A success rate of $53 \%$ was observed. Successful outcomes were more likely in adults and children aged more than 10 years [66].

Elluru RG, Dhanda R, Neely JG, Goebel JA. in 2001 studied about the efficacy and safety of anterior subannular tympanostomy in 38 consecutive patients with a diagnosis of Eustachian tube dysfunction, adhesive otitis media, or chronic otitis media with a perforation who underwent a tympanoplasty and concluded that Anterior subannular tympanostomy is a safe and effective method for long-term middle ear ventilation in patients with chronic eustachian tube dysfunction [67].

Nepal A, Bhandary S, Mishra SC, Singh I, Kumar P. in 2003-04 studied 100 cases with dry, clean central tympanic membrane perforations due to various causes like chronic suppurative otitis media-tubotympanic, post acute suppurative otitis media residual perforations or simple traumatic perforations with conductive hearing loss and without pre existing hearing loss were clinicoaudiologically evaluated and analyzed. The study concluded that hearing loss was found to be directly proportional to the size of perforation irrespective of their cause. Overall, perforations involving posterioinferior quadrant were found to have maximum hearing loss [68].

Gierek T, Slaska-Kaspera A et al.2004, compared the audiological results with temporalis fascia and tragal perichondrium and they concluded no statistically significant difference between the two [69].

Yetiser S, Hidir Y, Karatas E, Karapinar U. conducted a study on 30 patients who underwent ossicular chain reconstruction between 1990 and 2005, concluded that the success of the surgery was dictated by the location and the extent of tympanosclerotic involvement [70].

Mehta RP, Rosowski JJ, Voss SE, O'Neil E, Merchant SN. in 2006 studied patients with tympanic membrane perforations without other middle-ear disease. They concluded that the conductive hearing loss resulting from a tympanic membrane perforation is frequency-dependent, with the largest losses occurring at the lowest sound frequencies; increases as size of the perforation increases; varies inversely with volume of the middle ear and mastoid air space (losses are larger in ears with small volumes); and does not vary appreciably with location of the perforation. Effects of location, if any, are small [71].

Gierek T, Slaska-Kaspera A, Majzel K, Klimczak-Gołab L. in 2006 published a study that aimed to establish through a systemic review what is the best technique to treat tympanic perforations and concluded that there is no technique considered sure for every perforation neither technique definitive for type of perforation [69].
Haruo Takahashia, Hiroaki Satob, Hajime Nakamurac, Yasushi Naitod, Hiroshi Umekia. In 2007 examined the correlation between the middle-ear pressure regulation functions including active eustachian tube (ET) functions and transmucosal gas exchange function, and outcome of tympanoplasty and concluded that impairment of all the middle- ear pressure-regulation functions was likely to cause poor outcome of tympanoplasty, and also allowed us reconfirm that ears with mechanically obstructed ETs were contraindicated for tympanoplasty. Therefore, assessment of mastoid condition is important as well as the ET function before tympanoplasty [72].

H. Vijayendra, C. J. Ittop and R. Sangeetha in 2008 found that canaloplasty is an integral part of tympanoplasty and concluded that Canaloplasty gives $9 \mathrm{~dB}$ gain in hearing compared to without canaloplasty and gives better visualization, better graft placemen and better postoperative care [73].

Matsuda Y, Kurita T, Ueda Y, Ito S, Nakashima T. in 2009 found significant correlation between the degree of sound conduction disturbance and the perforation area; this correlation was greater at low frequencies following a traumatic perforation [74].

Ibekwe TS, Nwaorgu OG, Ijaduola TG, in 2009 studied the relationship between the location of perforation on TM and hearing loss and concluded that the location of perforation on the tympanic membrane (TM) has no effect on the magnitude of hearing loss in acute TM perforations while it is significant in chronic ones [75].

Warren Y. Adkins, M.D., Benjamin White, M.D.in 2009 studied about Type I tympanoplasties utilizing an underlay technique with temporalis fascia performed at the Medical University associated hospitals over a 5-year period were reviewed. In their study 40 adults were analyzed for influencing factors. The overall success rate was $89 \%$ and concluded that the age of the patient, the length of time the ear had been dry, and the presence of infection at the time of surgery had no influence on the success rate [76].

Kazim Bozdenir et al., 2011, in their comparative study, Tympanoplasty with island cartilage graft versus Temporalis fascia concluded that postoperatively, the pure tone averages and air-bone gap closure were better with temporalis fascia compared to cartilage grafting [77].

Rasha A, Ahmed SAO, 2015, in their study on outcome of hearing improvement in myringoplasty of 51 Sudanese Patients concluded that the temporalis fascia graft had better hearing threshold improvement [78].

Abhay Kumar, Prabhu Narayan, Prem Narain, Jaypal Singh, Prateek Kumar Porwal, Sanjay Sharma, Daya Shankar in 2018 did a comparative study between result of Temporalis muscle fascia and tragal cartilage perichondrium as a graft material in Type 1 tympanoplasty in 60 patients, dividing them into two groups. They concluded that in comparison to tragal cartilage perichondrium, tympanoplasty with temporalis fascia had better mean air conduction values [79]. 


\section{International Journal of Science and Research (IJSR) \\ ISSN: 2319-7064}

ResearchGate Impact Factor (2018): 0.28 | SJIF (2018): 7.426

Singh SP, Nagi RS, Singh J, 2018, did a comparative study on evaluation of audiological and graft uptake results of reinforced sliced cartilage versus temporalis muscle fascia graft in type I tympanoplasty. They concluded that sliced cartilage reinforced with temporalis fascia is a reliable technique for tympanoplasty, especially in large perforations with better graft uptake rates compared to temporalis fascia without affecting audiometric results [80].

\section{Conclusion}

In our study we concluded both temporalis fascia and tragal perichondrium are suitable graft materials for tympanoplasty. Graft uptake was superior with temporalis fascia, while hearing improvement was better with tragal perichondrium, although the results were not statistically significant.

Tragal perichondrial graft is an effective grafting material used for tympanoplasty due to its good qualities. Graft success rate was $97 \%$ in this study, which signifies yield of tragal perichondrial graft tympanoplasty.

Thus, to conclude, both temporalis fascia and tragal perichondrium are acceptable graft materials for successful closure of tympanic membrane perforations. The overall graft uptake appeared to be better with temporalis fascia, while the hearing improvement was better with tragal perichondrium. However, none of the results were statistically significant.

\section{References}

[1] Aristides Sismanis, MD. Tympanoplasty. In: Glasscock- Shambaugh SURGERY of the EAR. Ed; Micheal E Glasscock III, MD, Aina Julianna Gulya, MD.5th Ed; Elsevier publishers.2007: (Chapter 24), 463-485.

[2] Palva T. Surgical treatment of chronic middle ear disease. Myringoplasty and tympanoplasty. Acta Otolaryngol. 1987 Sep-Oct; 104 (3-4):279-84.

[3] Perkins R. Grafting materials and methods in reconstructive ear surgery. Ann Sep Otol Rhinol Laryngol. 1975 Jul-Aug; 84 (4 Pt 1): 518-26.

[4] Michael E Glasscock 111, George E. Shambaugh, jr., Surgery of the ear, 4th edition 1990.W.B.Saunder's Company.

[5] World Health Organisation/CIBA Foundation workshop reports, Prevention of Hearing Impairment from chronic otitis media, 1996.

[6] Rupa V, Jacob A, Joseph A.Chronic suppurative otitis media: prevalence and practices among rural South Indian children. Int J Pediatr Otorhinolaryngol.1999 May 25; 48 (3):21721.

[7] Salah Mansour et al Comprehensive and Clinical Anatomy of the Middle Ear 152- 165.

[8] Casale J, Giwa AO. Embryology, Branchial Arches. InStatPearls [Internet] 2019 Feb 27, Stat Pearls Publishing.

[9] Anthwal N, Thompson H. The development of the mammalian outer and middle ear. Journal of anatomy. 2016 Feb;228 (2):217-32.
[10] Szymanski A, Geiger Z. Anatomy, Head and Neck, Ear Tympanic Membrane. InStatPearls [Internet] 2019 Apr 6. StatPearls Publishing.

[11] Daniel E. Noise and hearing loss: a review. Journal of School Health. 2007 May;77 (5):225-31.

[12] Toyoda S, Shiraki N, Yamada S, Uwabe C, Imai H, Matsuda T, Yoneyama A, Takeda T, Takakuwa $\mathrm{T}$. Morphogenesis of the inner ear at different stages of normal human development. The Anatomical Record. 2015 Dec;298 (12):2081-90.

[13] Ječmenica J, Bajec-Opančina A, Ječmenica D. Genetic hearing impairment. Child's Nervous System. 2015 Apr 1;31 (4):515-9.

[14] Sánchez-Villagra MR, Gemballa S, Nummela S, Smith KK, Maier W. Ontogenetic and phylogenetic transformations of the ear ossicles in marsupial mammals. Journal of Morphology. 2002 Mar;251 (3):219-38.

[15] Hindi K, Alazzawi S, Raman R, Prepageran N, Rahmat K. Pneumatization of mastoid air cells, temporal bone, ethmoid and sphenoid sinuses. Any correlation?. Indian Journal of Otolaryngology and Head \& Neck Surgery. 2014 Dec 1;66 (4):429-36.

[16] Siddarthan M. A comparative study of cortical mastoidectomy with myringoplasty vs myringoplasty alone in active cases of chronic otitis media (Doctoral dissertation, Stanley Medical College, Chennai).

[17] Hussain B, Ali M, Qasim M, Masoud MS, Khan L. Hearing impairments, presbycusis and the possible therapeutic interventions. Biomedical Research and Therapy. 2017 Apr 20;4 (4):1228-45.

[18] Morrill S, He DZ. Apoptosis in inner ear sensory hair cells. Journal of otology. 2017 Dec 1;12 (4):151-64

[19] Branch IV MS, Chennai T. A Comparative Study of Cortical Mastoidectomy With Myringoplasty vs Myringoplasty Alone in Active Cases of Chronic Otitis Media.

[20] Mundra RK, Sinha R, Agrawal R. Tympanoplasty in subtotal perforation with graft supported by a slice of cartilage: a study with near $100 \%$ results. Indian Journal of Otolaryngology and Head \& Neck Surgery. 2013 Dec 1;65 (3):631-5.

[21] Barake R, El Natout T, Bassim M, El Natout MA. Loop underlay tympanoplasty for anterior, subtotal and total tympanic membrane perforations: a retrospective review. Journal of Otolaryngology-Head \& Neck Surgery. 2019 Dec;48 (1):12.

[22] Sergi B, Galli J, De Corso E, Parrilla C, Paludetti G. Overlay versus underlay myringoplasty: report of outcomes considering closure of perforation and hearing function. Acta Otorhinolaryngologica Italica. 2011 Dec;31 (6):366.

[23] Patil K, Baisakhiya N, Deshmukh PT. Evaluation of different graft material in type 1 tympanoplasty. Indian Journal of Otology. 2014 Jul 1;20 (3):106.

[24] Freitas MR, Oliveira TC. The role of different types of grafts in tympanoplasty. Brazilian journal of otorhinolaryngology. 2014 Aug;80 (4):275-6.

[25] Merkus P, Kemp P, Ziylan F, Yung M. Classifications of mastoid and middle ear surgery: A scoping review. The journal of international advanced otology. 2018 Aug;14 (2):227. 


\section{International Journal of Science and Research (IJSR) \\ ISSN: 2319-7064}

ResearchGate Impact Factor (2018): 0.28 | SJIF (2018): 7.426

[26] Sarkar S. A review on the history of tympanoplasty. Indian Journal of Otolaryngology and Head \& Neck Surgery. 2013 Dec 1;65 (3):455-60.

[27] Adip K. Shetty, Haritosh K. Velankar, Akanksha A. Saberwal, Yogesh G. Dabholkar, Sharad Bhalekar, Devayani Shinde."Temporalis Fascia versus Tragal Perichondrium -A Comparative study of Outcomes as Graft Material in Tympanoplasty".Journal of Evolution of Medical and Dental Sciences 2013; Vol. 2, Issue 52, December 30; Page: 10172-10176

[28] M. Mohsen Wafaie comparative study of the clinical and audiological outcome of myringoplasty using temporalis fascia graft versus tragal cartilage graft aamj, vol. 8, n. 2, april, 2010.

[29]R. K. Mundra • Richi Sinha • Richa AgrawalTympanoplasty in Subtotal Perforation with Graft Supported by a Slice of Cartilage: A Study with near $100 \%$ ResultsIndian J Otolaryngol Head Neck Surg (December 2013) 65 (Suppl 3):S631-S635; DOI 10.1007/s12070-013-0673

[30] Emily IacovouIs et al cartilage better than temporalis muscle fascia in type I Tympanoplasty? Implications for current surgical practice Eur Arch Otorhinolaryngol, DOI 10.1007/s00405-012-2329-4

[31] Matthew Yung et al Randomized Study Comparing Fascia and Cartilage Grafts in Myringoplasty Annals of Otology, Rhinology \& Laryngology 120 (8):535541.

[32] Rajeev Reddy. "Comparative Study of Results of Cartilage-Perichondrium vs. Temporalis Fascia Grafting in Active Tubotympanic Type of Chronic Suppurative Otitis Media". Journal of Evolution of Medical and Dental Sciences 2014; Vol. 3, Issue 24, June 16; Page: 6714-6720, DOI: 10.14260/jemds/2014/2809

[33] K. Cagdas Kazikdas et al. Palisade cartilage tympanoplasty for management of subtotal perforations: a comparison with the temporalis fascia technique Eur Arch Otorhinolaryngol (2007) 264:985-989 DOI 10.1007/s00405-007-0291-3

[34]Zahnert T, Huttenbrink KB, Murbe D, Bornitz M (2000) Experimental investigations of the use of cartilage in tympanic membrane reconstruction. Am J Otol 21:322-328?

[35] Yakup Yegin Comparison of temporalis muscle fascia and full-thickness cartilage grafts in type 1 tympanoplasty Int J Clin Exp Med 2016; 9 (5):87318736

[36] M M KHAN, S R PARABComparative study of sliced tragal cartilage and Temporalis fascia in type I tympanoplastyThe Journal of Laryngology \& Otology (2015), 129, 16-22

[37] M. Mohsen Wafaie comparative study of the clinical and audiological outcome of myringoplasty using temporalis fascia graft versus tragal cartilage graft aamj, vol. 8, n. 2, april, 2010

[38] Rahul K. Jaiswal1Comparison of outcomes of palisade cartilage with temporalis fascia following tympanoplasty at a tertiary care centre in Nepal. Int $\mathbf{J}$ Otorhinolaryngol Head Neck Surg. 2016 Oct; 2 (4):224- 229doi:10.1017/S0022215114003132

[39] Sohil Vadiya Comparison of Modified Cartilage Shieldf Tympanoplasty with Tympanoplasty Using
Temporalis Fascia Only: Retrospective Analysis of 142 Cases Scientifica Volume 2016, Article ID 8092328, 4 pages http://dx.doi.org/10.1155/2016/8092328

[40] Uzun C, Caye-Thomasen P, Andersen J, Tos M. A tympanometric comparison of tympanoplasty with cartilage palisades or fasciaafter surgery for tensa holesteatoma in children. Laryngoscope2003; 113:1751Y7.

[41]Lee CF, Chen JH, Chou YF, Hsu LP, Chen PR, Liu TC. Optimal grafthickness for different sizes of tympanic membrane perforation in cartilagemyringoplasty: a finite element analysis. Laryngoscope 2007; 117:725-730.

[42] Cabra J, Monoux A. Efficacy of cartilage palisade tympanoplasty: randomised controlled trial. Otol Neurotol 2010; 31: 589-95.

[43] Juveria Majeed, Naveed Ahamed. Comparative Study Between Temporalis Fascia And Tragal Perichondrium In Myringoplasty. Journal of Dental and Medical Sciences. 2016; 15 (11): 64-72.

[44] Octegren U. Atca Otolaryngol Suppl.1964, 193:1-43.

[45] Ashok K. Saha, D.M. Munsi, S.N.Ghosh. Evaluation of improvement of hearing in type I tympoanoplasty $\&$ its influencing factors. Indian J. of otolaryngology and $\mathrm{H} \& \mathrm{~N}$ surgery. $2006 ; 58$ (3): 253-57

[46] Ilana Fukuchi, Dafne Patrícia Cerchiari, Eduardo Garcia, Carlos Eduardo Borges Rezende, Priscila Bogar Rapoport. Tympanoplasty: Surgical results and a comparison of the factors that may interfere in their success. Rev Bras Otorrinolaringol 2006; 72 (2):26771.

[47] S. K. Nagle, M. V. Jagade, S. R. Gandhi, P.V. Pawar. Comparative study of outcome of type 1 tympanoplasty in dry and wet ear. Indian J Otolaryngol Head Neck Surg (April- June 2009); 61:138-140.

[48] Goyal Rashmi. Role of cortical mastoidectomy in type 1 tympanoplasty. Indian Journal of Otology 2010;16:8-12.

[49] R Akayleh, Amman-Jordon, M Alroosan. The surgical outcome of myringoplasty in adults in the Royal Medical Services. Khartoum Medical Journal (2012); Vol. 05, No.3, pp. $816-818$.

[50] Adnan Saleem Umar, Zubair Ahmed. Anatomical and functional outcome following type-1 tympanoplasty in chronic tubotympanic suppurative otitis media. Pak Armed Forces Med J Mar 2008; 58 (1):62-7.

[51] Karela M. Myringoplasty: surgical outcomes and hearing improvement: is it worth performing to improve hearing? Eur Arch Otorhinolaryngol September2008; 265 (9): 1039-42.

[52] Sheehy JL, Anderson RG. Myringoplasty. A review of 472 cases. Ann Otol Rhinol Laryngol. 1980 Jul-Aug; 89 (4 Pt 1):331-4.

[53] Gibb AG, Chang SK. Myringoplasty (A review of 365 operations). J Laryngol Otol. 1982, Oct; 96 (10):91530.

[54] Vartiainen E, Nuutinen J. Success and pitfalls in myringoplasty: follow-up study of 404 cases. Am J Otol. 1993 May; 14 (3):301-5

\section{Volume 8 Issue 12, December 2019}




\section{International Journal of Science and Research (IJSR) \\ ISSN: 2319-7064}

ResearchGate Impact Factor (2018): 0.28 | SJIF (2018): 7.426

[55] Al-Ghamdi SA. Tympanoplasty: Factors influencing surgical outcome. Ann Saudi Med. 1994 Nov; 14 (6):483-5.

[56] Seung Hyo Choi, Ju Hee Han, Jong Woo Chung. Preoperative evaluation of Eustachian tube function using a modified pressure equilibration test is predictive of good postoperative hearing and middle ear aeration in type 1 tympanoplasty patients. Clinical and Experimental Otorhinolaryngology. 2009; 2 (2):61-65.

[57] Jain K, Pandey A, Gupta S, Rahul. A Clinical Study of Hearing Outcome after Type I Tympanoplasty. IAIM, 2016; 3 (10): 48-54.

[58]Lee JC, Lee SR, Nam JK, Lee TH, Kwon JK. Comparison of different grafting techniques in type I tympanoplasty. Otol.Neurotol. 2012; 33:586---90.9

[59] Palva T. Surgical treatment of chronic middle ear disease. Myringoplasty and tympanoplasty. Acta Otolaryngol. 1987 Sep-Oct;104 (3-4):279-84.

[60] Michael E Glasscock 111, George E. Shambaugh, jr., Surgery of the ear, 4th edition 1990.W.B.Saunder's Company.

[61] Packer P.et al. What's best in Myringoplasty: Underlay or Overlay, dura or fascia? The journal of Laryngology and otology, January 1982, 96.pp 25-41.

[62]Bawa G.S., A.S. Khurana, and Harvinder Singh. Comparitive evaluation of Auto graft Temporalis fascia and Homogta ft duramater in Tympanoplasty. Indian journal of otolaryngology, 1987; 39.No 3:September, pp.102-103.

[63] Sato H, Nakamura H, Honjo I, Hayashi M. Eustachian tube function in tympanoplasty. Acta Otolaryngol Suppl. 1990; 471:9-12.

[64] Vartiainen E, Nuutinen J. Success and pitfalls in myringoplasty: follow-up study of 404 cases. Am J Otol. 1993 May; 14 (3):301-5.

[65] Kotecha B, Fowler S, Topham J. Myringoplasty: a prospective audit study. Clin Otolaryngol Allied Sci. 1999 Apr; 24 (2):126-9

[66] Mak D, MacKendrick A, Weeks S, Plant AJ. Middleear disease in remote Aboriginal Australia: a field assessment of surgical outcomes. J Laryngol Otol. 2000 Jan; 114 (1):26- 32.

[67] Elluru RG, Dhanda R, Neely JG, Goebel JA. Anterior subannular T-tube for prolonged middle ear ventilation during tympanoplasty: evaluation of efficacy and complications. Otol Neurotol. 2001 Nov; 22 (6):761-5.

[68] Nepal A, Bhandary S, Mishra SC, Singh I, Kumar P. The morphology of central tympanic membrane perforations. Nepal Med Coll J. 2007 Dec; 9 (4):239. 44.

[69] Gierek T, Slaska-Kaspera A, Majzel K, KlimczakGołab L. Results of myringoplasty and type I tympanoplasty with the use of fascia, cartilage and perichondrium grafts. Otolaryngol Pol. 2004; 58 (3):529-33.

[70] Yetiser S, Hidir Y. Temporalis fascia and cartilageperichondrium composite shield grafts for reconstruction of the tympanic membrane. Ann Otol Rhinol Laryngol. 2009 Aug; 118 (8):570-4.

[71] Mehta RP, Rosowski JJ, Voss SE, O'Neil E, Merchant SN. Determinants of hearing loss in perforations of the tympanic membrane. Otol Neurotol. 2006 Feb; 27 (2):136-43

[72]Haruo Takahashia, Hiroaki Satob, Hajime Nakamurac, Yasushi Naitod, Hiroshi Umekia. Correlation between middle-ear pressure-regulation functions and outcome of type-I tympanoplasty. (June 2007); Volume 34, Issue 2, Pages 173-176.

[73]H. Vijayendra. C.J.Ittop. R.Sangeetha. Comparitive study of hearing improvement in type 1 tympaoplasty with and without canaloplasty. Indian J. Otolaryngol. Head Neck surg. 2008; 60:341-344.

[74] Matsuda Y, Kurit T, Ueda Y, Ito S, Nakashima T. Effect of tympanic membrane perforation on middleear sound transmission J Laryngol Otol Suppl. 2009 May; (31):81- 9

[75] Ibekwe TS, Nwaorgu OG, Ijaduola TG. BMC. Correlating the site of tympanic membrane perforation with Hearing loss. Ear Nose Throat Disorders 2009 Jan4; 9:1.

[76] Adkins WY, White B. Type I tympanoplasty: influencing factors. Laryngoscope. 2009 January; 94 (7):916-8.

[77] Kazim Bozdemir et.al., Tympanoplasty with island cartilage or Tempoalis fascia: A comparative study.2011 Nov; 10:14:02.

[78] Rasha A, Ahmed SAO. Outcome of Hearing Improvement in Myringoplasty. A Study of Fifty One Sudanese Patients. International Journal of Otorhinolaryngology. 2015; Vol. 1, No. 1, pp. 5-8.

[79] Abhay Kumar, Prabhu Narayan, Prem Narain, Jaypal Singh, Prateek Kumar Porwal, Sanjay Sharma, Daya Shankar.Comparative study between result of Temporalis muscle fascia and tragal cartilage perichondrium as a graft material in Type 1 tympanoplasty. International Journal of Otorhinolaryngology and Head and Neck Surgery 2018 Mar; 4 (2):565-568

[80] Singh SP, Nagi RS, Singh J a comparative evaluation of audiological and graft uptake results of reinforced sliced conchal cartilage versus temporalis muscle fascia graft in type I tympanoplasty. Int J Clin Exp Otolaryngol. 2018; 4 (1):96100 